\title{
DENSTONE EXPEDITION TO \\ INACCESSIBLE ISLAND
}

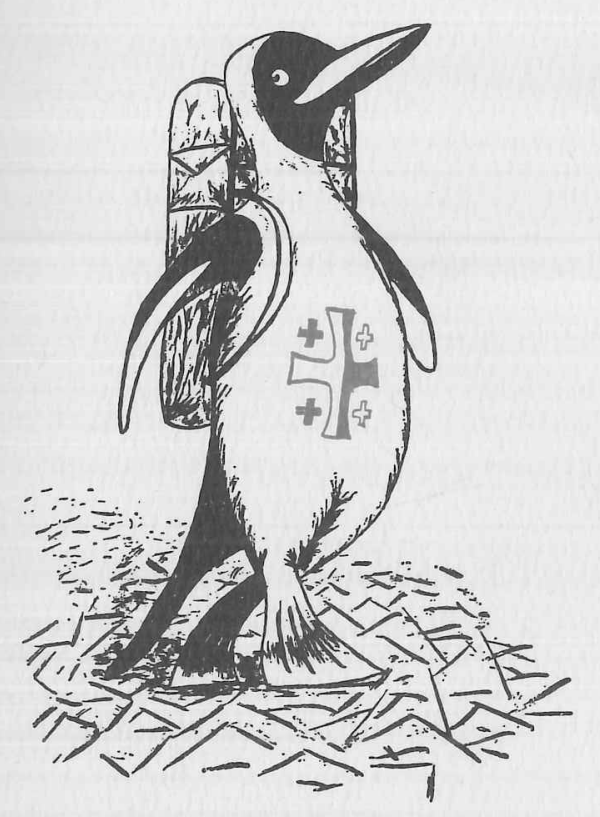




\section{CONTENTS}

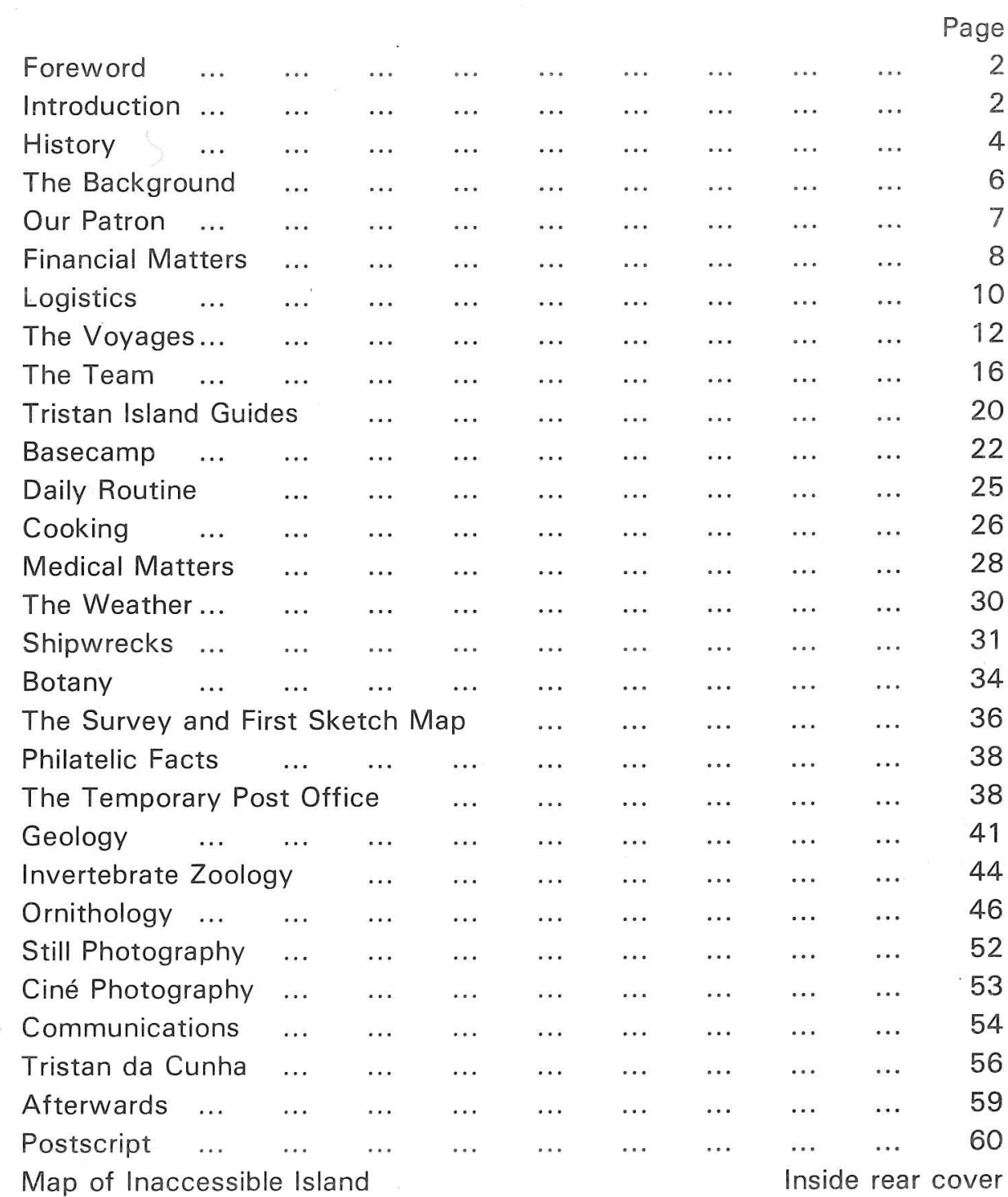

Contributors: Michael Fraser, David Gilfillan, Nick Hall, Richard Holt, Niall Mateer, Richard Preece, Clive Siddall, Michael Swales, John Woolley and Dominic Dowsett. 


\section{FOREWORD}

I write this Foreword with mixed feelings: A great deal of pride and satisfaction that we as a School were able to mount and successfully carry out such a major scientific enterprise; profound gratitude to so many individuals, old boys, parents, staff, pupils and friends, all of whom I consider to be "the School;" thankfulness that throughout the five months we had no accident or serious illness; and a little envy, as I had hoped to be 'there' for some of the time myself. Nevertheless, I was part of it, as was the School as a whole. The party on Inaccessible was only the sharp-end, seen by the public; the Expedition was a communal effort and all who helped, in whatever way, were members.

The following pages, contributed by the sharp-end team, give some flavour of what was experienced and it is our hope that it will encourage others to think of, plan and complete their own adventures.

T.G.B.

\section{INTRODUCTION}

The Denstone Expedition to Inaccessible Island (the "D.E.I.") was a College venture whose aims, under the leadership of M. K. Swales, were to explore and to make the first shore-based map of this Island in the Tristan da Cunha Group, South Atlantic Ocean. The sixteen-man team consisted of seven seniors who were mostly experts in their fields, six pupils who were their assistants, and three Tristan Islanders who acted as guides.

After four years of planning and preparation, the main party left Denstone on 2nd October, 1982, and flew to Cape Town. They continued from there by sea, calling briefly at Gough Island and Tristan before being landed by helicopter on Inaccessible Island on 16th October. After six weeks on the Island, two members returned to waiting jobs in England and were replaced by three others in January. The main party was taken off Inaccessible on 23rd December to spend a month on Tristan as guests of the Islanders, before returning to Inaccessible.

The Expedition was relieved from Inaccessible by helicopters of the Royal Navy on 10th February, taken to Tristan for a further week before returning to Cape Town and thence home to England, landing at Heathrow on 28th February, 1983. The major objectives were achieved successfully during the four months spent on Inaccessible Island and without any injury to personnel.

The success of this venture is due largely to the very many people who helped and supported us. To all of them, in addition to the few named in these pages, we express our most sincere thanks.

M.K.S.

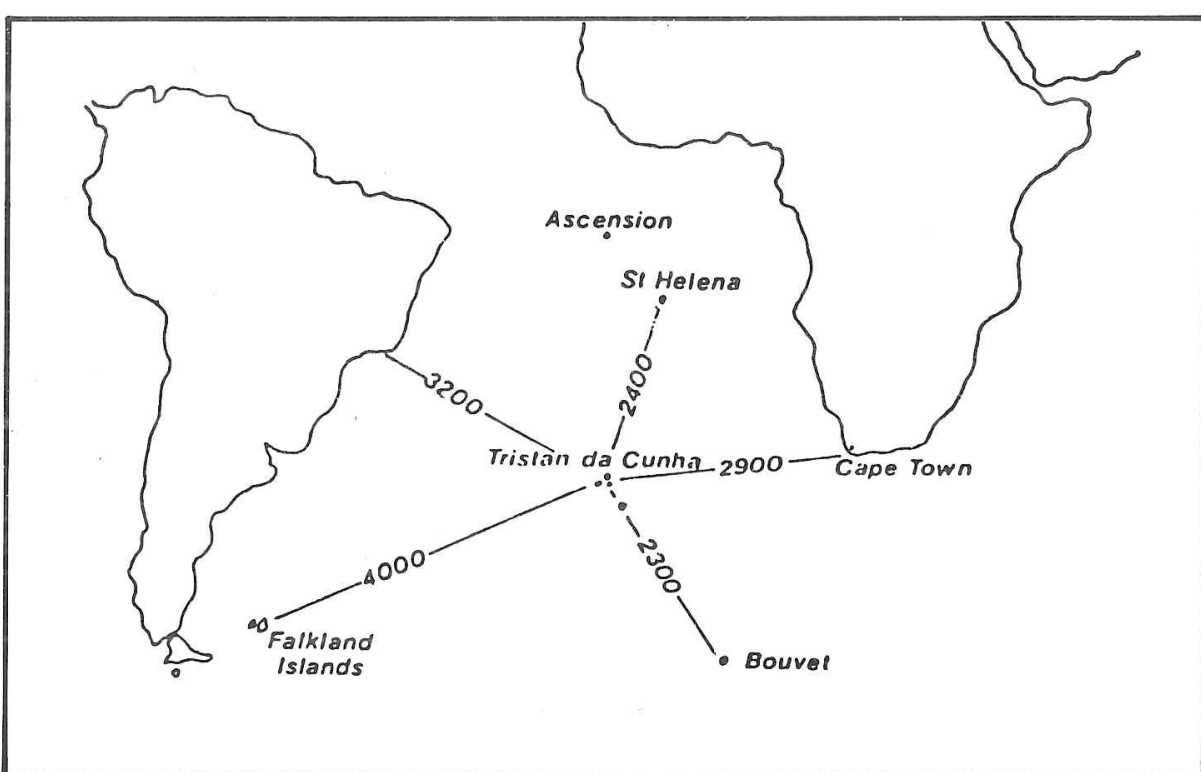

Location of the Tristan da Cunha Group (distances in km).

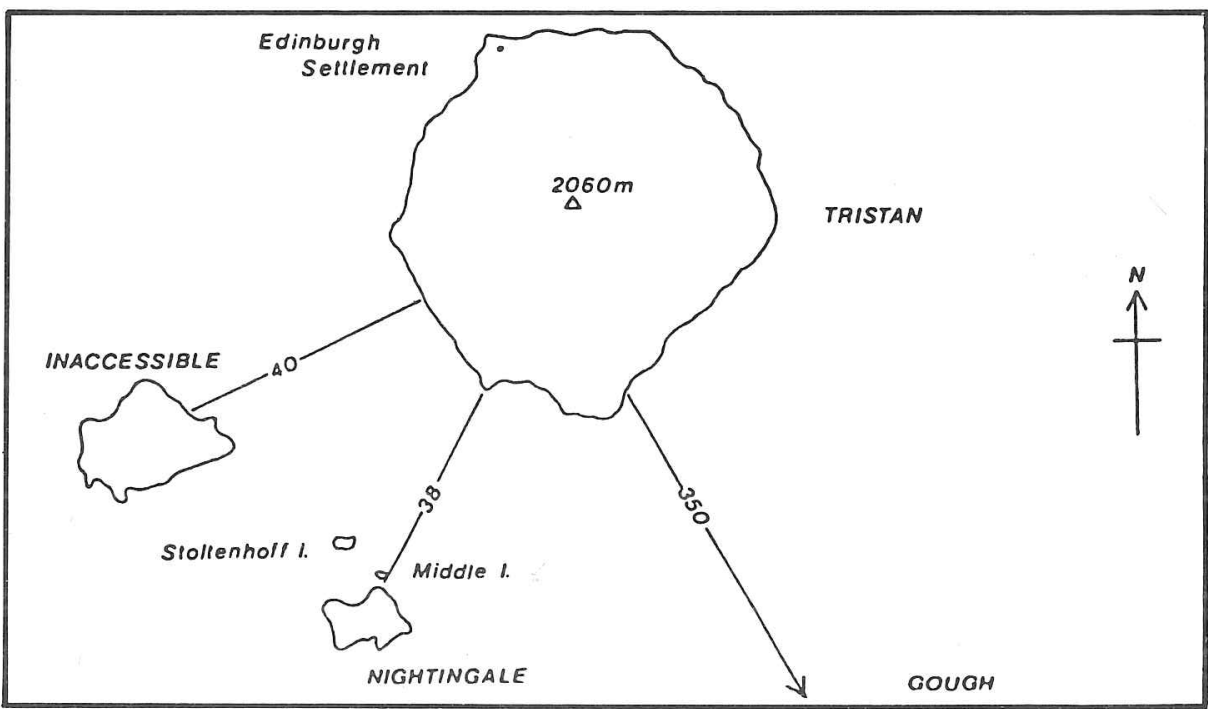

Location of Inaccessible Island (distances in $\mathrm{km}$ ) 


\section{HISTORY}

Apart from the ill-fated foundering of the Blenden Hall described elsewhere, Inaccessible Island has rarely been visited. Originally visited by the Dutch ship 't'Nachtglas' in 1652 and named after it, the word 'inaccessible' was added in parenthesis after the name because the sailors sent ashore were unable to get further than the beach! This description has persisted as the name.

Some time after Cpl. Glass and his family settled on Tristan in 1816, and perhaps as a result of the Blenden Hall affair, goats and pigs were put ashore on Inaccessible as a permanent source of fresh meat. These were there in some numbers when the two German brothers Stoltenhoff landed in 1871, hoping to make their fortune from sealing, and were an important aid to their survival during the following two winters, as aptly described in the book about their adventures "Shelter from the Spray." There are no domestic animals on Inaccessible Island today.

It was in 1873, when H.M.S. 'Challenger' called at Inaccessible and rescued the Stoltenhoffs, that the first scientists went ashore there-for a few hours only - and drew attention to the interesting flora and fauna. In 1922 Shackleton's ship, the 'Quest,' called briefly and it was then that the thickbilled Bunting was discovered and named after the ship's biologist, Wilkins. In 1938, some members of the Norwegian Scientific Expedition to Tristan called at Inaccessible after visiting Nightingale Island and spent three weeks ashore during which time they got on to the plateau and made some limited collections of birds, plants and rocks.

The Tristan Islanders have occasionally visited Inaccessible, but for no real purpose - the natural resources of birds and their eggs and guano were less abundant there than on Nightingale; but several ex-patriates have made the journey from Tristan. Hence the discovery of the Inaccessible Island flightless rail which was named 'rogersi' after a missionary to Tristan. One of the Administrators (Sir Hugh Elliott) even spent a fortnight's holiday there and took the first ciné film on the Island - an interesting and valuable resource which we studied closely during the planning of our Expedition. Following the eruption of the volcano on Tristan, the Royal Society sent out an expedition in 1962; geologists in the party made a geological map of Inaccessible from their ship and went ashore to collect rock specimens; but got no further than the beach. Several maps were made in this way from the sea and, in 1961, the first aerial photographs were attempted but unsuccessful due to cloud covering the island. A visiting botanist (N. M. Wace) had to abandon his attempt in 1968 to get inland and even left his rope hanging on the cliff at Waterfall Beach. So, no shore-based map existed and the ship-drawn ones varied considerably from one another.

Two points of note resulted from our study of the historical records. First, we made contact with one of the few descendants of one of the Stoltenhoff brothers, a Mr. J. Humby living in England and very interested to learn about the temporary home of his forbears. Second, we wrongly thought the idea place for our base would be near the waterfall cascading 300 metres ove the cliffs at Waterfall Beach. We were later to discover that, had we landed there, we would have been trapped-it was no longer possible to climb up there. So, we were fortunate indeed in being put ashore at Blenden Hall, the only place from where there is access to the interior.

The cliffs of Inaccessible Island rising $400 \mathrm{~m}$ sheer from the beach and giving it its name.

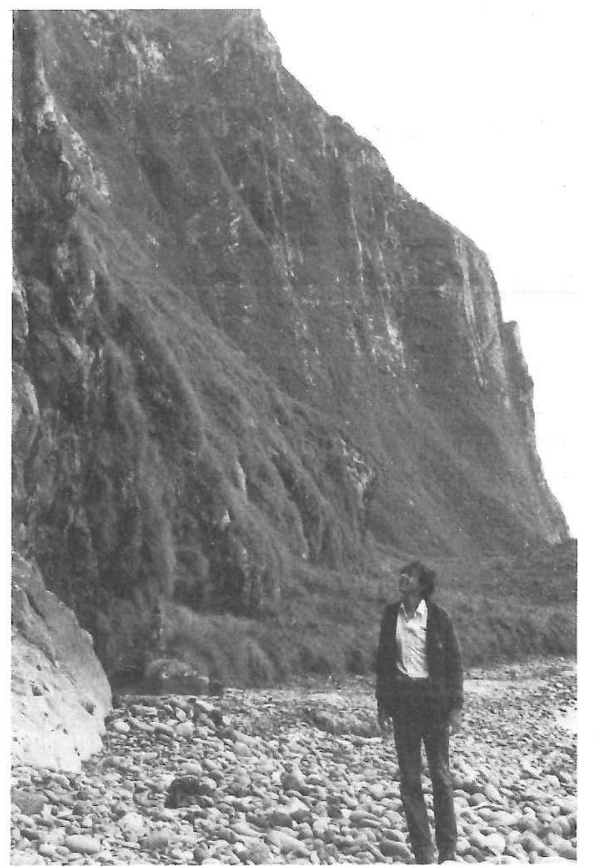

It had been planned after the Second World War to develop Inaccessible Island as a farm for Tristan - a plan which fortunately fell through; but one of the Islanders who took part in the original pilot scheme was Nelson Green who became one of our guides. Not only did he remember where spring water flowed at Blenden Hall, and hence where our camp should be situated, but also the way up the cliff from there. It turned out that he also remembered the previous state of the vegetation and was able to give us valuable comparisons with the present status of certain plants.

Our study of the history told us much more: Of fires (the tussock on Inaccessible had twice been on fire and burnt for months), of a cave inland in which a person could shelter (though we found only fissures which would however repay further investigation), of sea monsters (we saw whales, sharks, octopuses, sea elephants and seals); but there was a certain amount of fiction also and we can easily imagine the difficulty of confusing it with fact on such a fascinating Island. 


\section{THE BACKGROUND}

They say a new broom sweeps clean: In September 1978, our new Headmaster, Mr. Tim Beynon, arrived and, within a few weeks during his first term, called me to his study and said he would like me to launch and lead a major scientific expedition from Denstone! A feasibility study was undertaken which showed that such a project was feasible and various possible venues were suggested: Northwest Canada, Mongolia, the Chilean Andes and Inaccessible Island in the Tristan da Cunha Group. Without hesitation, he selected the last of these as our destination; we were to explore and map this isolated Island in the middle of the South Atlantic Ocean. The date was then November 1978 and the project was announced to the Staff on December 1 st.

Much of the following school holidays was spent in drawing-up plans, a prospectus and a budget. Fortunately, I had first hand experience of the area, having been on the Expedition which first explored Gough Island, $350 \mathrm{~km}$ South of Tristan. I appreciated something of how difficult my task was going to be, but little guessed the actual difficulties which lay ahead. Also I knew some of those to consult, especially Dr. Martin Holdgate who led that Expedition and was now President of the Young Explorers' Trust. My brief was such that ours was not so much to be a schoolboy expedition as a scientific expedition in which pupils took part.

Inaccessible Island is the second largest of the Tristan Group lying 2,900 km West of Cape Town and somewhat further from Rio de Janeiro, or $10,000 \mathrm{~km}$ South of Denstone. Uninhabited and hitherto largely unexplored and unmapped from ashore, it is a volcanic remnant measuring approximately $4 \times 5 \mathrm{~km}$ and surrounded by sheer cliffs up to $430 \mathrm{~m}$ high on all sides - hence the name. It is just $40 \mathrm{~km}$ Southwest of Tristan, but this is across the open South Atlantic and Tristan Islanders rarely go there. The beaches and off-shore reefs are treacherous: Several shipwrecks are known to have occurred, the most famous of which, that of the Blenden Hall in 1821 is described below. The nearest shipping lanes today are over $1,000 \mathrm{~km}$ to the North and West, the only ships visiting Tristan normally being supply and small fishing vessels, apart from yachts making for the Cape. Only six previous visits by scientists had taken place, all of short duration and most failing to gain access to the interior. The attaining of our objectives (to explore and map) was thus long overdue. Our planned departure date was originally during the Autumn of 1980.

Early in 1979, I held a general meeting of all interested pupils who had previously signed a list. They had to be those who would have taken their $\mathrm{O}$ or A levels in the Summer of 1980. About sixty had signed: I needed six. Selection was going to be a long and complex procedure, but the interest was certainly there. The party was to consist of six or seven adults, O.D.'s or Staff who were specialists in the major scientific disciplines plus surveying, and the pupils were to be their assistants. It was also planned to take two or three Tristan Islanders who would act as guides.
Selection of assistants took place over the next six months after which training for the lucky few began. This took place at an isolated camp site in the Lake District during two separate weeks in the following twelve months. Owing to the very large number of other preparation details, it was not possible for us to have more training camps, much though we should have liked to do so. Personal (especially fitness) training was thus advised and a scheme recommended. Selection of the experts was, if anything, more difficult. They not only had to be proficient, they had to be available to go. Unemployment helped a little, but the ideal was an employable, fully-qualified person who was going to be between jobs over the period October-February.

Selection was eventually completed, but then disappointment struck. As described below, shortage of funds caused last-minute postponement of our departure. This was heart-breaking for all concerned: Some would inevitably be unable to go at a later date, others had actually altered their plans in order to be free to go; fortunately, no-one suffered as a result of the postponement. Two years later, in October 1982, the modified team consisting of pupils past and present, bar one, set off and went on to achieve the original objectives successfully.

\section{OUR PATRON}

The concept of patronage for an expedition is a very old one, but is still applicable today if only for major private ventures like ours. Whereas formerly the advantage was chiefly financial, nowadays it is more a matter of prestige and of adding authenticity to the enterprise.

It was therefore agreed at an early stage in D.E.I. planning that we should seek a Patron. Various approaches were made jointly with the help of two members of the School Council and, in due course we were invited to apply, through his Private Secretary, to His Royal Highness the Duke of Gloucester. In July 1981, he graciously consented to be our Patron. At no time was this privilege to be used in connection with our fund-raising, but we were allowed to quote his patronage on our notepaper and this undoubtedly helped our image. We were most grateful to be so honoured, especially as it was His Royal Highness' mother who had laid the foundation stone for the College Centenary Building in 1972.

On the day before the main party set off for Inaccessible, we received the following message of good wishes from our Patron:

"I send you all my best wishes for a most successful Expedition and you can rest assured that I am much looking forward to receiving news and reports on your progress. I hope you have a very productive and enjoyable voyage. RICHARD, Patron, Denstone Expedition.' 
His Royal Highness was kept informed of our progress at intervals while we were in the field. On our return, we learnt that a Reception had been arranged to take place at the Royal Geographical Society's house for 3rd May and that His Royal Highness would be pleased to attend, and we would be presented to him.

The Reception was essentially an occasion for Expedition members, their families and friends. A party of seventy in all gathered at 6.00 p.m. At 6.15, His Royal Highness was met and welcomed at the front door of the R.G.S. by Mike Swales, Expedition Leader and Tim Beynon, Headmaster, then conducted to the New Map Room. There, everyone was introduced to him in turn, informally. Some had been a little daunted at this prospect, but need not have been for he put us at ease by his most charming manner. He showed great interest in everything to do with the Expedition, especially in the exhibition of Dominic's colour photographs and Clive's new sketch map of Inaccessible. After an hour, the gathering was quiet for Mike to make a small presentation to His Royal Highness as an expression of our gratitude for his patronage. In his reply, the Duke said he had found it most interesting to be our Patron, congratulated us on the success of the venture and said that in particular he hoped that each member had learnt something about himself on Inaccessible Island which would be of lasting benefit. Soon afterwards, His Royal Highness left for further engagements, a buffet supper was served (appropriately by Crown Caterers) and a memorable evening came to a conclusion. Our thanks for it are due to the Director of the Royal Geographical Society and to our energetic. Bursar for making all the arrangements for us.

\section{FINANCIAL MATTERS}

Fund-raising for expeditions has never been easy. Someone once said that the first $f 500$ is the most difficult to raise. We soon found out that there is more than a grain of truth in this. The initial budget figures showed that $£ 20,000$ would be the cost of this Expedition and this sum was to be raised in a little under two years.

The normal methods of fund-raising for expeditions are: Seeking sponsorship from both individuals and firms (for which very many letters have to be written and the success rate is never more than 10 per cent), fund-raising events, sale of memorabilia, applying to Trusts and professional Bodies. We tried all of these and all the members became involved in letter-writing. Our very first donation was of $£ 5$ from a parent. In addition, it was made clear in selection interviews that members would be required to make a personal contribution of $£ 900$ each towards Expedition funds if at all possible, though this was not intended as an absolute bar to selection.
To raise the order of sum required, we needed a number of large donations and the main source of these was thought likely to be sponsors. Unfortunately for us, a general recession began in this country in 1979; so our main hope became one major fund-raising effort, the "Sale of the Eighties," a large auction sale planned for early September 1980 . This was a success and raised

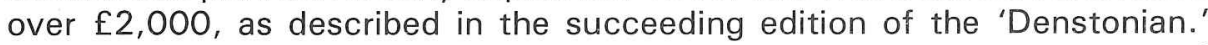
Although a number of Trust funds and professional Bodies made grants of up to $f 1,000$ each, it became clear that we should not reach our target in time. So, most reluctantly and after much careful thought and discussion, the Expedition's departure was postponed for two years at the eleventh hour - a bitter blow to us all.

The postponement did give us some advantage: We gained a breathing space, in which it was possible to consolidate our plans generally, as well as to go on fund-raising. By now, this had become a communal effort involving many members of the College community, not least many loyal parents and Old Denstonians plus the many pupils who designed and were selling (and buying) our memorabilia-biros, tee-shirts, mugs, ties, etc. not to mention our penguin mascot. However, by now the recession was beginning to bite, the funds we had accumulated were depreciating and people were less willing to give generally. It was therefore decided that we must safeguard what funds we had by both investment and by seeking exemption from income tax. To achieve the latter, we needed charitable status. So, out of hardship was borne the Denstone Expeditions Trust, set up with the help of our legal advisor with the long-term aim of supporting worthwhile expeditions from Denstone, the first of which was to be the D.E.I.

In many ways, the next two years became a race against depreciation and inflation: Our original budget estimate rose at an alarming rate to at least double, with no end to the increase in view. Fortunately, manufacturers increasingly preferred to make donations in kind rather than cash and these eventually accounted for one third of the value of our total assets and, furthermore, we were able to store them. By July 1982, it looked as though we had enough funds to be able to commit ourselves to booking our air fares: The Expedition was 'on' for October-provided shipping could be found in time to take us on from Cape Town and later to collect us from Inaccessible Island. That was to be the subject of another story, as also is the clearing of all the expenses we were yet to incur... 


\section{LOGISTICS}

The planning and preparation of this major scientific Expedition took almost four years. The job was deputed to Michael Swales as Head of Science at Denstone by the Headmaster and with the approval of the School Council. Formal permission had then to be obtained from the British Foreign Office and the Tristan Island Council, followed by approval from certain major scientific and exploration Bodies in England: the Royal Society, the Royal Geographical Society, the Young Explorers' Trust, and the Scott Polar Research Institute. After this, funds had to be raised. The original budgetted total was estimated at $f 20,000$; but this rose continuously with inflation to more than double, a fact not helped by the recession.

The Expedition food and equipment all had to be obtained, assembled, packed and shipped to arrive on Inaccessible Island with the Expedition. Catering was worked out on the basis of an expected 1,200 man-days in the field and much of the food had to be specially packed in England to withstand the journey, as well as to last up to three months on the Island. The Expedition's accommodation on the Island consisted of a specially designed and constructed sectional wooden $40^{\prime} \times 20^{\prime}$ house which also had to be shipped out from England.

Clothing was carefully planned to protect members from high winds and heavy rain, as well as to withstand heavy wear in the field. Scientific equipment was assembled to cater for the needs of all the major scientific disciplines concerned. Paraffin was chosen as the main fuel and had to be shipped out in appropriate containers; a wind generator was to supply electricity as a supplementary energy source. In all, about twelve tonnes of supplies and equipment, from about 100 firms, were landed on Inaccessible Island, most of it shipped out by container to Cape Town, there transhipped and eventually landed by helicopter.

Transport was a major and vital item to arrange. Owing to the isolated position of the Tristan Group, mid-way between South Africa and South America, in the South Atlantic, very few ships go there and those that do are mostly small with limited passenger facilities. Further, they would be unlikely to go to or from the islands just when we wanted-in October and February. There was the further problem that, even if we found a ship to take us, it would be most unlikely to go further with us than Tristan; the last $40 \mathrm{~km}$ could prove our downfall. One major sticking point was also insurance: we were too great a risk!
Extensive enquiries worldwide among cruise and freight lines met with little success and possible help was reduced to coming from: the Royal Navy the South African Government, Tristan Investments Ltd, and St. Helena Shipping. In the event, all four played a vital part. The main party of ten was taken out from Cape Town in the 'SA Agulhas' and landed on Inaccessible Island on October 16th, 1982; two members were brought back and three more taken out in December/January by the m.f.v. 'Tristania II'; H.M.S 'Endurance' evacuated the main party on February 10th, 1983, to nearby Tristan, from where we were returned to Cape Town in the R.M.S. 'Aragonite." The long outward and homeward (London-Cape Town) legs of the journey were by commercial air flights of South African Airways. Clearly, we were extremely fortunate with weather and sea conditions, as well as ship movements, to land on and set off from Inaccessible Island on schedule. 


\section{THE VOYAGES}

Although many people at Denstone are seasoned air travellers, few have experienced long ocean voyages nowadays. So, most of us regarded the long flights to and from Cape Town as rather tedious, even if the baggage weigh ins were rather hazardous; but the prospect of the outward sea-voyage met with no response. However, after the first visit to the 'SA Agulhas' in Cape Town docks and our first meeting with Capt. Leith who made it clear that he was a 'no-nonsense' sailor, some began to wonder what lay ahead.

So, as the main party sailed from Cape Town on a dull Spring morning, there was a distinct sense of despondency rather than of elation. However, Mike Fraser wrote in the Log on the first day out that "the 'SA Agulhas' is to our relief a fine craft with not even the slightest tendency to sink." However, next day, Gilfie wrote "the sea is choppy to say the least and many members are feeling its effects!" As if to take minds off such things, the party was soon organised so that each took a turn on watch and, at other times set about learning to identify the numerous seabirds - many of them belonging to species we were to get to know well on Inaccessible. Thus, the time between meals ("all we seem to do in this ship is eat!") became fully occupied: Life at sea was quite a pleasant way to travel after all.

After five days at sea, the impressively modern, fast ship arrived of Gough Island, about $3,000 \mathrm{~km}$ out and $350 \mathrm{~km}$ South of Tristan. Here, she was due to off-load stores and here we got the first taste of off-shore line fishing - photos of the poop deck at this stage look rather like a fish quay when the fleet has just returned to port. It was also our first sight of really large numbers of seabirds as they congregated on the sea at dusk before going to their breeding grounds ashore. However, owing to a certain monotony of routine, it was also a time when we began to wonder if we should ever ge ashore on Inaccessible and, more important, if and when we were ever going to be taken off again.

Plans and preparations were made for the landing and, on 15th October, the 'Agulhas' sailed for Tristan where two Island guides, Nelson and Andrew, were taken aboard. Next evening, we were put ashore by helicopter on the only part of Inaccessible where, as it turned out, there was access to the interior. One person wrote in the Log later: "I would have expected the first touch on Inaccessible soil to be an emotional affair, but it certainly wasn't because of the great deal of hard work that had to be done ..." That part is developed in another article below.

Six weeks later, on 29th November, the time came for the departure of John and Richard from Inaccessible, to return to waiting jobs in England. A posse of Islanders came over from Tristan in two launches with rowing boats in tow to come ashore in. It had been fine earlier in the day, but the weathe was deteriorating and there was quite a swell breaking on Blenden Hall beach by the time they arrived. This treacherous beach where the ship of that name foundered in 1821 had been running true to form: A landing would only have been possible on three occasions during the previous six weeks. The Islanders superb seamanship enabled them to achieve their purpose now; besides the two seniors, they also took off Andrev, Nelson and David Gilfillan who had not been well. The passage back to Tristan in the tiny launches was an experience none of them will forget: Although only $40 \mathrm{~km}$, the crossing is of the open South Atlantic and on the edge of the Roaring Forties - facts which speak for themselves. Again, owing to the Islanders' skill, a safe landfall was made on Tristan after $3 \frac{1}{2}$ hours.

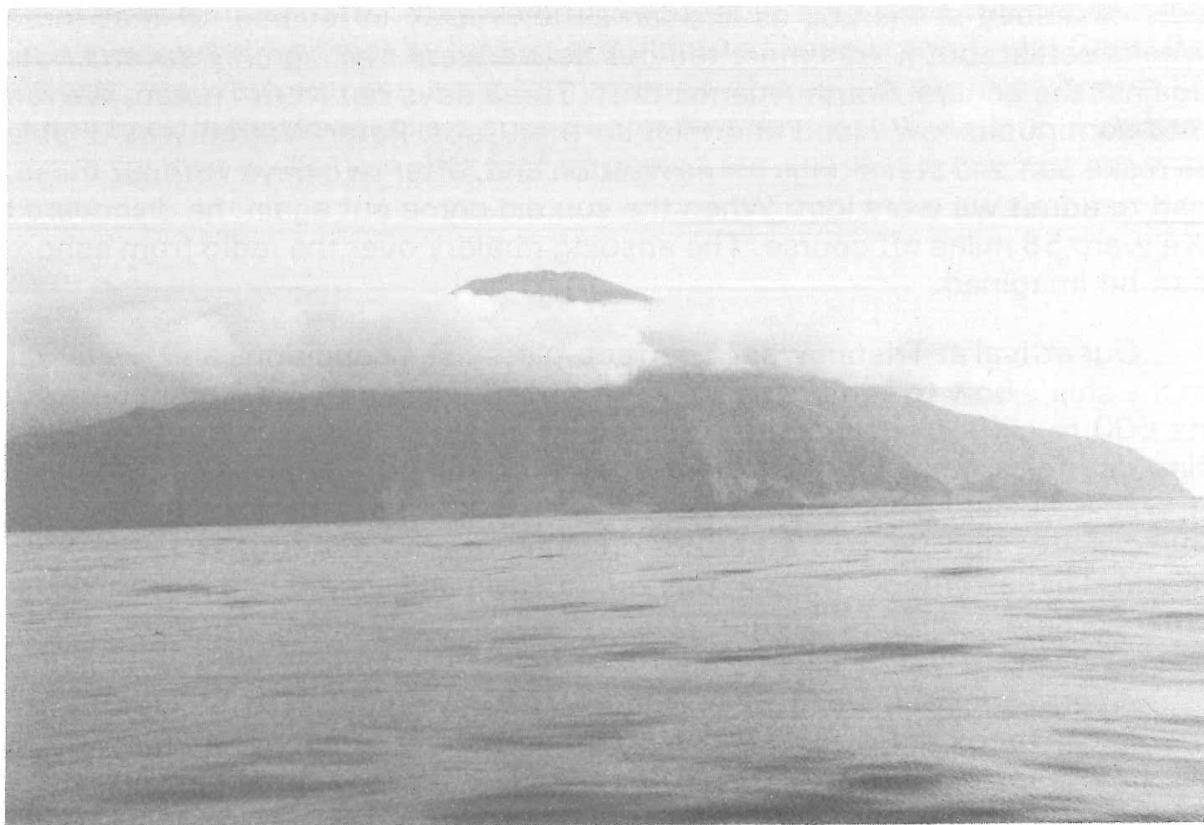

Tristan da Cunha on an exceptionally calm day with the Peak showing above the cloud.

A week later, John and Richard went aboard the 646 ton fishing vessel 'Tristania II' in readiness for returning to the Cape in her three days later. In that time, they gained their first taste of life in a small vessel fishing in those waters, paradoxically off Inaccessible for most of the time. They were able to keep in close contact with those still ashore, as well as to get good close views of all sides of the Island: They soon appreciated how difficult it is to map an island from the sea - all that had been done previously for Inaccessible. On 9th December, 'Tristania' set sail for the Cape: 2,900 km at 9 knots. Naturally, comparisons with the 'Agulhas' were made, which exceeded the smaller vessel in all but one respect-food! By the time the two reached Cape Town, they had logged a total of twenty days at sea in the South Atlantic in addition to visiting some of the remotest islands in the world. 
Meanwhile, ten thousand $\mathrm{km}$ away at Denstone, two others (Mike and Dom.) were already preparing to return in the 'Tristania' three weeks later. In John and Richard's de-briefing (which lasted 13 hours) it was made clea that the Expedition was greatly missing a geologist on Inaccessible. By good fortune and thanks to the generosity of an oil millionaire, Niall Mateer was able to join us at short notice and had the longest journey of all from Texas, to meet up with us in Cape Town. There, we were all looked after extremely well for the few days of our stay by the Expedition's Agent, O.D. Bernard Hill, and his wife Brenda. The voyage which followed from the Cape to Tristan was described in the Log as like 'an action replay in reverse' of that three weeks earlier; but it was more tedious as we were making only seven knots against the general South Atlantic drift. Three days out from Tristan, we ran into continuous low cloud and mist so that Capt. Peter Warren was unable to make sun and star sitings for navigation and, after two days without these had to admit we were lost! When the sun did come out again, he discovered we were 58 miles off course. The ensuing ribaldry over the radio from ashore can be imagined.

Our arrival at Tristan was in perfect, glassy sea conditions and we all sat in the ship's bow to admire the idyllic setting of Edinburgh Settlement beneath its $600 \mathrm{~m}$ cliffs overtopped by the $2,080 \mathrm{~m}$ peak. This was the first really fine day for a month, so the main party was still on Tristan. Next morning, it was still fine when we boarded the two launches to take us back to naccessible and we had a perfect crossing and a 'smooth' landing on the sland. That afternoon, the weather broke again and stayed bad for two days: How fortunate we had been.

A fortnight later, we received a long cable saying that H.M.S. 'Endurance' would call for us at 0600 hours on 10 th February. The tempo of work on the Island increased and packing was done in the hope that we should complete all and that, on the day, the weather would be fine. It was: At 0600 precisely, the ship steamed into view round North Point with siren sounding, Aldis lamp flashing and all navigation lights on-quite a sight. We lit a fire on the beach to identify our position and, over the radio, indicated our readiness for departure. The two Wasp helicopters soon came over and, after a slight hesitation, landed on the clearing we had made for them in the tussock. Two hours later, we and all our specimens, equipment and luggage were safely aboard. M.K.S., one of the first to be lifted off Inaccessible, was quickly taken to the Bridge to be introduced to Capt. Colin McGregor and an old College acquaintance John Massingham who, three hours later, was piped ashore as His Excellency the Governor of St. Helena visiting his Protectorate of Tristan da Cunha.
A further week was spent on Tristan before the R.M.S. 'Aragonite' arrived from St. Helena en route for the Cape. Fond farewells were said, with tears, ashore and on board before she set sail at 3.00 p.m. on 17 th. We passed to 'the eastward' round the Island as far as Sandy Point, and then away, with Tristan, Inaccessible and Nightingale Islands all in view for a time. Tristan, the highest, was last to sink below the horizon as night fell with all of us leaning against the rail in very pensive mood. "One hell of an experience that was" said one of the team as he turned away: We all agreed.

A week later, after an uneventful but most enjoyable voyage in which our every need was met by a most attentive and happy crew under Capt. Bob Wyatt, we were awoken early to the sound of crashing china on board: We were back in the Cape rollers again. Later that day, 24th February, 1983, we were back in civilisation. We had all gained our sea-legs since last we were there. 


\section{THE TEAM}

The following took part in the Expedition:

Ian Best-Assistant

David Briggs - Assistant

Jonathan Dakin - Assistant

Dominic Dowsett-Assistant

Michael Fraser-Ornithologist

David Gilfillan-Assistant

Andrew Glass - Tristan Islander

Nelson Green - Tristan /slander

Harold Green - Tristan Islander

Nick Hall-Doctor, Botanist and Co-Leader

Richard Holt-Assistant

Niall Mateer-Geologis.t

Richard Preece-Invertebrate Zoologist

Clive Siddall-Surveyor

Michael Swales - Leader and Ciné-Photographer

John Wooley-Co-Leader and Cook

"An excellent body of men"-so quoted the sage, but it could have been applied to the Expedition Team. After the long selection procedure referred to elsewhere, it is perhaps not surprising that each was 'up to' a venture of this nature; but the 1980 postponement had caused four of those originally selected to withdraw. This, coupled with the late withdrawal of two more and the deferred departure of the Leader, hardly made for stability in the Team. However, it proved to be a very happy, united group of men who explored Inaccessible Island. There was only one argument recorded in the whole five month venture; so, clearly, we all got on well together. A short biographical note on each follows for the record.

Beginning with the youngest, Dom. Dowsett and Dave Gilfillan (Gilfie to his many friends in the South Atlantic now) were only 16 and had recently taken their ' $\mathrm{O}$ ' levels. Both coped with the severe physical challenge of the Expedition well. Dominic, as ciné assistant, competently carried heavy photographic gear with comparative ease wherever required. David took on the chore of climbing the mountain for the alternate-day radio 'sched.' with Tristan not only uncomplainingly, but with enthusiasm.

lan Best (who became known as "Heen" on Tristan) Dave Briggs, Jo Dakin and Rick Holt had all taken their ' $A$ ' levels and were taking the year 'off' before going on to further education. At 18 and 19 they were perhaps better able to cope with the ruggedness of the Island and, like all of us, grew very fit in the process - even to bursting out of clothes! lan and Dave became keen ornithologists, making a significant contribution on that side of the scientific work. lan also took charge of the wind generator very conscientiously and successfully. Jo became a keen and competent assistant surveyor, tramping the whole Island with heavy equipment during the four months on
Inaccessible. Richard started by assisting in the collection of Invertebrates but, after Richard Preece left in November, took over the whole of this important area of study very competently. He was also a very conscientious and thorough assistant to the Postmaster and his written account of this experience occurs below.

Clive Siddall had completed two years of his university course in Engineering and took a year's leave of absence to go on the Expedition. Originally intended to assist in mapping the Island, he was promoted to Surveyor when Adrian Wareham withdrew from the Team. With the minimum of training, he thus undertook one of the most responsible tasks of the whole venture. The measure of his success, and on which he is to be congratulated, is to be seen on his Map of Inaccessible Island. He has also produced larger scale maps of small parts of the Island to help the scientists with their work. His account of the Survey occurs below.

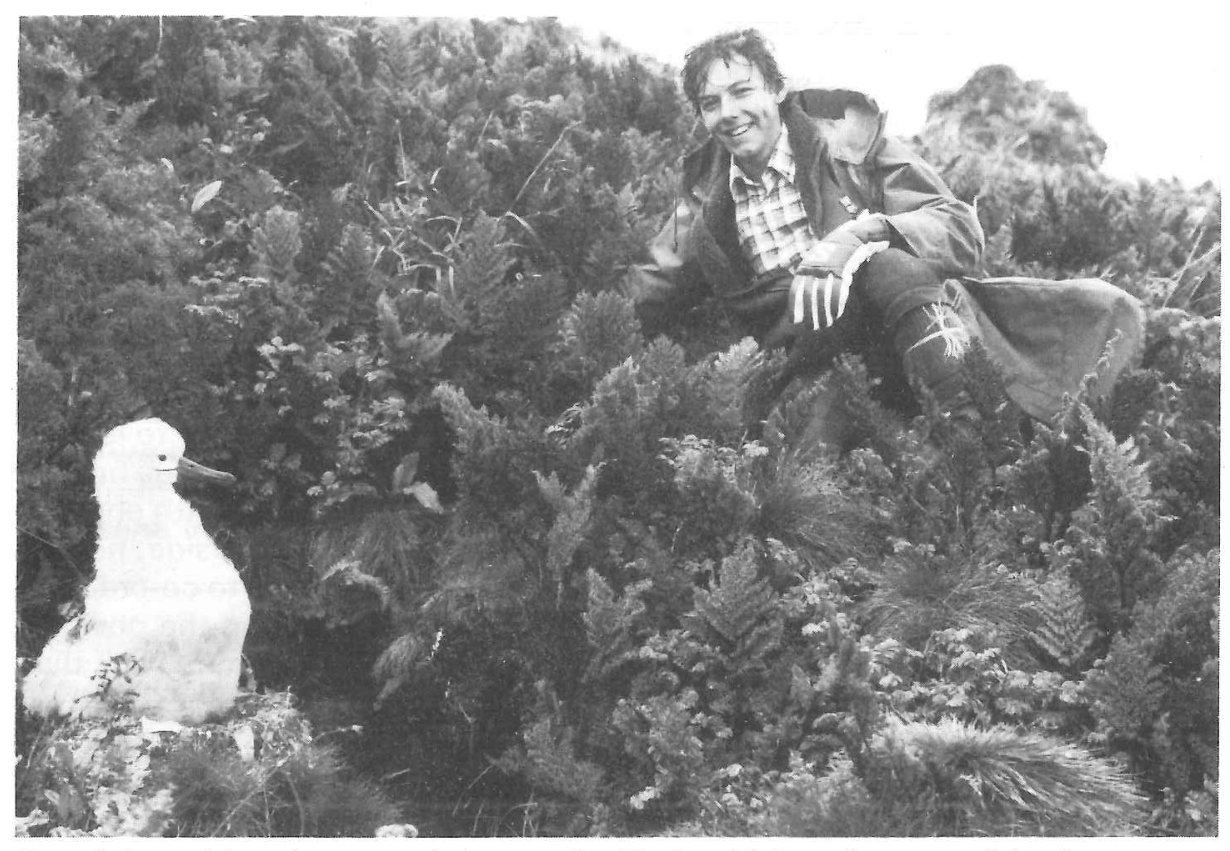

Dominic making the acquaintance of a Molly chick on Inaccessible. Any nearer and he would have been sprayed with a foul-smelling oil!

Mike Fraser was the only non-Denstonian in the party - he was educated at Merchiston but we didn't hold that against him. Invited to join the party as ornithologist at short notice after the withdrawal of Tim Beynon, he had potentially the largest job on the scientific side. His competence was evidenced from an early stage when he not only mastered the intricacies of seabird identification himself, but organised seabird watches on board the 'Agulhas' 
for the rest of us and soon taught everone how to distinguish some of the more difficult species to identify from the heaving deck of a ship. His keen powers of observation were matched by his wry sense of humour and his unflappability, both of which endeared him to all and quickly welded him into the Team. It is noteworthy that he was offered a research post at Cape Town University on our way home at the end of the Expedition.

Richard Preece's interest in snails has taken him on to academic research, most recently at Cambridge. Whereas he would be collecting a wide range of invertebrates on Inaccessible, he was well qualified to investigate clues about the biological history of the Island. As these are to be found laid down in peat, it was not surprising that he soon took a keen interest in the peat bog at Blenden Hall. Richard also discovered new species of snails on the Island and these, along with much other material deposited at the British Museum (Natural History) are now being studied by specialists.

Niall Mateer was able to join the Expedition thanks to the generosity of a benefactor ( $\mathrm{Mr}$. Jack Grimm) in Abilene, Texas where Niall is Head of the Geology Department at McMurry College. Niall's job was to map the geological features of Inaccessible and to make a collection of rocks, all of which would tell more about the Island's past. In the face of considerable obstacles, not least the weather, the topography and the overlying vegetation, Niall achieved his main objectives in a mere three weeks. It says much for his personality that he did this without a particular assistant but, rather, with the help of all and sundry.

Nick Hall had long been interested in Botany, but was encouraged to study Medicine in which he duly qualified. He was thus the ideal person to join us as Expedition Doctor and Botanist. In his latter capacity, he had a full briefto make the first extensive botanic collection from Inaccessible with obvious exciting possibilities of making new discoveries. On the medical side, he had a somewhat awesome responsibility. In addition, he undertook to co-ordinate the still photography then, at the eleventh hour, he was put in the position of taking on the Co-leadership with John Woolley. It says much for Nick that he undertook this increased responsibility without complaint and he went on to contribute much to the team spirit among members.

It is not every day that a busy independent school Headmaster is asked to join an expedition at short notice and accepts! But such was the case with John Woolley. When misfortune struck Mike Swales in September 1982, he had a fortnight to find someone to take over the leadership. Nick nobly undertook responsibility for the scientific programme, John was asked to take over the administrative side-he freely admitted to having no scientific experience. Fortunately he agreed and was able to leave his school for a term. He then survived probably the most hectic fortnight of his life, followed by a nerve-racking time co-ordinating the details of the Cape and beyond. Once on Inaccessible, he became Cook - a vital job at all times but especially during the early stages. An idea of his miraculous achievements with the most basic equipment and limited supplies is given separately below.

When he finally caught up with the party in mid-January, Mike Swales found a co-ordinated team in the best of spirits. Feeling almost an intruder by then, he gently took over some of the reins again but, by then, the Team aimost ran itself. Wherever there were jobs to be done, they were donecheerfully and efficiently. Resourcefulness and initiative had been used to the full so that the scientific programme and survey were completed on time. Lasting friendships had been made on Tristan where it was evident that the community was filled with admiration for the Blenden Hall Boys (as they had by now become known) and for what they had achieved. With no wish to embarass any, it is interesting to note that the Team impressed others on their way back home too, various unsolicited testimonials being received. Perhaps it should also be added that two members (Richard Preece and Niall) each got married since our return, while a third (Clive) has become engaged.

It had been said by some that this was 'only a schoolboy Expedition.' Nothing could have been further from the truth, as demonstrated by our achievements as well as by the make-up of the Team. The D.E.I. was a major scientific Expedition on which a number of the personnel happened to be of school age. Naturally, we owe much for our success to our back-up members who contributed so much on our behalf. In particular: Peter Pine-Coffin, our Treasurer, resident auctioneer and globe-trotter extra-ordinary; Bernard Hill our Overseas Agent in Cape Town; Michael Collis our Legal Advisor and, not least, Tim Beynon our Headmaster. To all of these we are specially grateful for all their time, trouble and effort on our behalf. It is therefore hoped that what we have achieved together may be an encouragement to others to set out from schools on reasonably ambitious scientific expeditions, from Denstone in particular, supported by the new D.E.T. 


\section{TRISTAN ISLAND GUIDES}

Like so many island people, the Tristan Islanders are somewhat shy and retiring; but, when you get to know them, most hospitable and friendly with a fine sense of humour and loyalty. Also, like many other islanders, they are very able fishermen and fine seamen-especially true on Tristan where their livelihood and even survival may depend on these two qualities.

The Tristan community owes its existence largely to the willingness of a number of shipwrecked sailors over the years to face the challenge of survival on the world's loneliest Island. The first colonist was, however, in the army one Cpl. Glass and he obtained permission to stay, with his wife and family, after having been posted there as part of a garrison in 1816, when Napoleon was a prisoner on St. Helena, 2,400 km to the North. One of his direc descendants is Andrew Glass who accompanied us to Inaccessible. An energetic 57-we celebrated his birthday on the Island with a special party - he is head shepherd on Tristan and thinks nothing of setting off in the small hours to round up sheep on the 'Base' there, involving a $600 \mathrm{~m}$ climb and back before breakfast. It was fitting that he should have landed with our main party and helped us to pioneer the route onto the escarpment.

Nelson Green, at 68 the eldest of our three, is no less energetic. He had been to Inaccessible before, years ago when an abortive attempt had been made to start a farm on the Island. He therefore remembered certain important details - it was he who advised the siting of our hut just where the clearest spring water is. Nelson accompanied the Expedition throughout our stay on Inaccessible and we were many times glad of his delightful sense of humour with twinkling eye. He was always ready to turn his hand to anything, especially cooking and showed us a number of excellent Tristan recipes.

Harold Green was the junior of the three Islanders in age - a mere 47-but with the most expedition experience. He had been a guide with Mike on Gough 27 years before and had been there again subsequently, taking on the responsibility for some scientific records on Tristan also. A strong man, he willingly helped our surveyors, Clive and Jo, with the arduous carrying of equipment to the furthest parts of Inaccessible. A devout man with strong character also, he had been Chief Islander on Tristan, so his influence helped us obtain the use of a dinghy when we returned to Inaccessible in January. Apart from the usual accomplishments of fishing and seamanship, Harold's forté was barbecue cooking; hence our enjoyment of fried 'petrel' chicks on Salt Beach and the 'braaie' by the roaring surf for our final party on Blenden Hall Beach.

The three Islanders put us to shame with their fitness, being able to go anywhere faster and carrying greater loads; but they fitted in with our Team remarkably well and played a full part in all that we did. Only once did we persuade them to do something against their better judgement: To row round to Salt Beach when the sea appeared calm but still had a swell running which

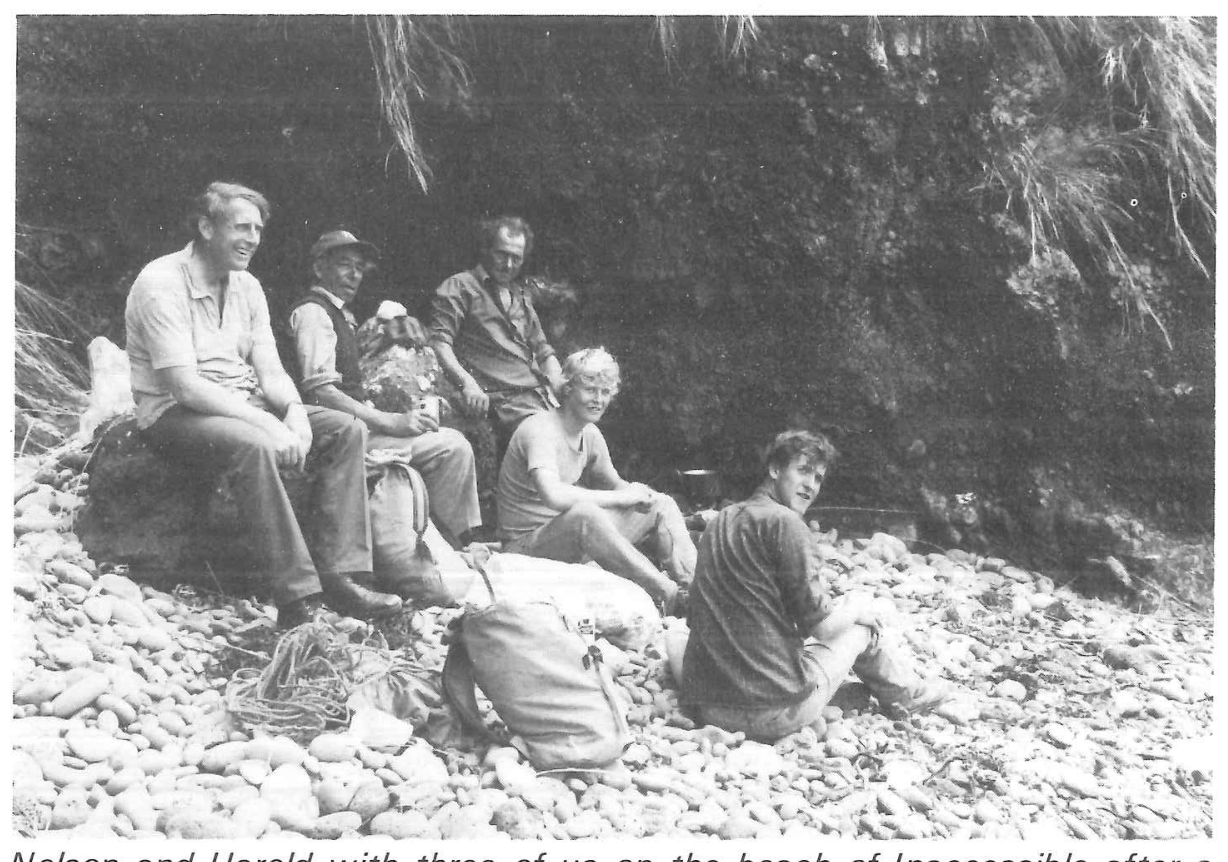

$\mathrm{Nelson}$ and Harold with three of us on the beach of Inaccessible after a specially-cooked picnic.

prevented us from landing when we got there; so we had to row all the way back again, by now in pouring rain - we learnt our lesson. There was also the occasion when one of them decided to act against his own inclination and go collecting 'haigs' on a Sunday: John who accompanied him got very excited at the prospect of discovering hidden booty, until he realised it was the Great Shearwater laying season!

Like all the other Islanders, 'our' three showered kindness upon us and each invited us to 'big heaps' in his home back on Tristan. We greatly appreciated having had the privilege of living with Andrew, Nelson and Harold and of having them accompany us and teach us so much, and are sincerely grateful to them. 


\section{BASECAMP}

From the earliest stage in the Expedition planning, it was clear that we should have to take more permanent accommodation with us to Inaccessible Island than tents. These would however be necessary in the initial stages and for subsidiary camps elsewhere than at our base on the Island.

It was clear also that, whatever building we erected as our base must be able to withstand extremes of wind and rain, must be large enough to provide all that was necessary - for sleeping, eating, cooking and laboratory work - for sixteen people at a price we could afford. Our Leader's experience on a similar expedition to Gough Island, $350 \mathrm{~km}$ to the South of Tristan, led to the immediate consideration of a sectional wooden main building with two smaller ones as store-huts. But we were to be twice as many as on that expedition, with correspondingly more equipment. A large enough house was likely to be beyond our means.

Plans were drawn up but were not convincing; so professional help was sought-from architecture students at a polytechnic to whom it was offered as a design project. The results came back suggesting the use of various materials from cardboard to polystyrene and fibreglass. Not surprisingly, we reverted to the original idea of a sectional wooden construction measuring 40 feet by 20 feet. Fortunately, we also received a cost-price offer to manufacture to our specifications; so Wernick's of Wickford in Essex got the contract and duly delivered on time in mid-July 1982. Fortunately, the weathe was dry when their enormous fully-laden lorry came up the drive, weaving its way round the chestnut trees, so that the sections (over 100 of them) were all light in weight when off-loaded into the Drill Hall. We immediately had a practice in house-building: Two of us could manage each section easily and four of us put up a third of the building in two hours. It was unlikely to be so easy on Inaccessible.

One important factor was that the roof sections of our new building were twenty feet across. This meant we required a forty foot container to hold the hut and all our other equipment. Thereafter, the Drill Hall took on the appearance of a warehouse as everything else for the Expedition arrived and was packed, a process which took a further six weeks and many plastic wrappers generously provided by I.C.I. Plastics Division. Amongst the many items there were the parts of two tubular metal-framed $(6 \times 10 \mathrm{foot})$ buildings They were to be covered by heavy duty polythene and would be our store huts, though they could also sleep people in an emergency. They would require little initial levelling of ground and could be erected quickly. We were gratefu to the parent who provided them, as well as to the O.D. who gave us the tents

Five weeks after leaving Denstone (on 9th September, 1982), these and all our other equipment were landed on Inaccessible Island by helicopter in just two hours. One moment of anxiety during this operation was when the downdraft from the rotor blades started blowing the hut sections about like

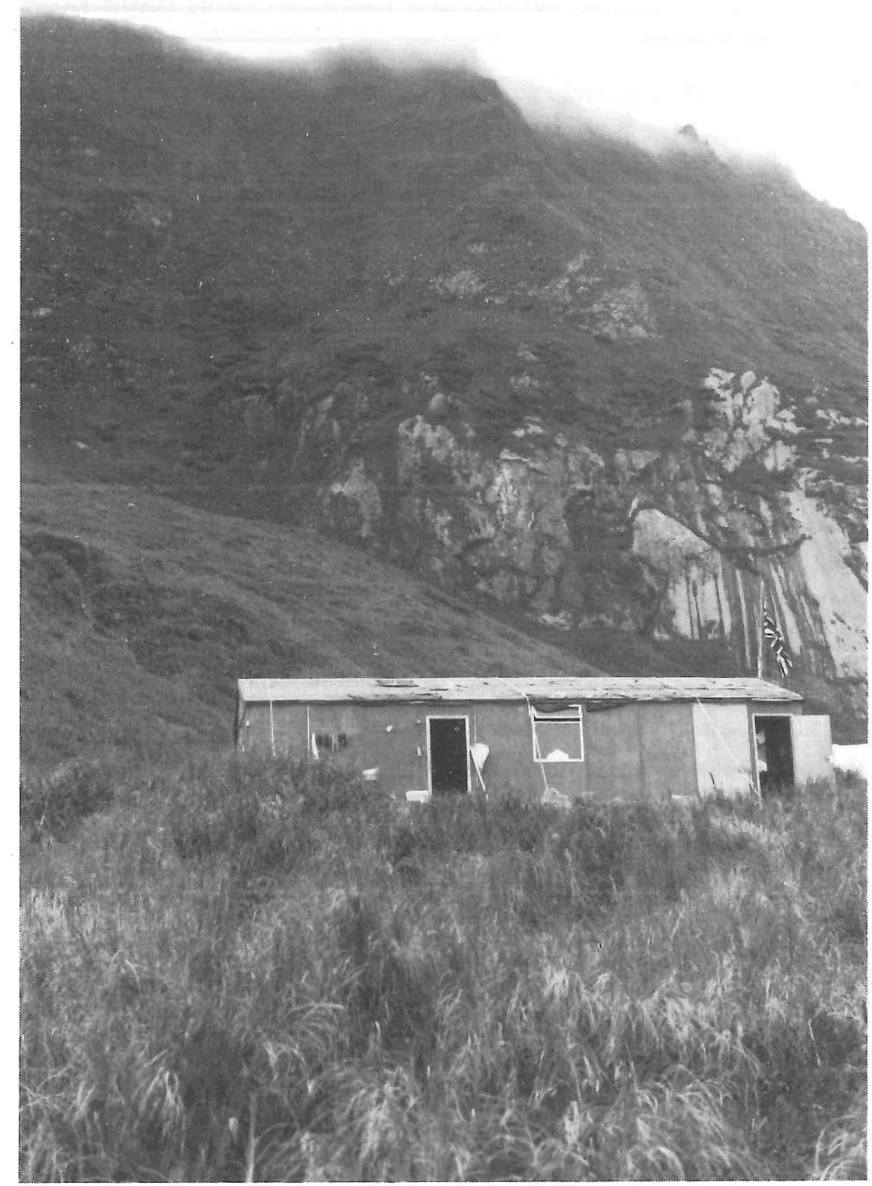

The D.E.I. hut set among tussock at Blenden Hall with the cliffs towering behind.

straw in the wind! Fortunately, none was lost. However, the real work was then about to begin: It took the next three and a half days to clear and level the site for the hut, though only 24 hours to erect it after that. So, the main party was sleeping in the hut after five days on the Island during which time the weather was generally fine and the discomforts not too severe.

Once set up, the furniture (chiefly our bunks) had to be assembled and positioned within the hut. We had designed these and had had the timber (again generously donated by an O.D.) cut and planed at Coll. Jo Dakin now showed his skill as a master carpenter and the bunks were all assembled in one day - the nails for this purpose were a gift from G.K.N. He further 
constructed all the working surfaces (using mostly packing cases) and the dining table (a door set on drift wood legs). One of the seats at table was a large wooden capstan from the beach, which we believe could have been from the wreck of the Blenden Hall.

Our sleeping and living accommodation was in one large, central room off which opened the kitchen at one end, the laboratory at the other. All the bunks were two-tiered except two which, naturally, tended to be used as the communal settees or additional lab. benches, not always to the liking of whoever slept there. The roof trusses were so designed that clothes could be slung from them, a much-used facility except in the regions where the roof leaked!

On the whole, the Expedition hut served us well. Though we feared the ends might be blown in until we had further reinforced them, and the roo be lifted off by the wind until anchored by three one-inch thick ropes, it withstood the elements well apart from a few small leaks. It was therefore decided not to dismantle it before we left and, although it looked rather forlorn after the Union Jack had been lowered for the last time, we hear it has withstood its first Winter storms and remains a facility on the Island for the use of others. We dismantled and removed all else when we left Inaccessible.

\section{DAILY ROUTINE}

As an Expedition with major objectives to be achieved in a fixed time, we had to make the most of the daylight hours on Inaccessible Island. Early rising was essential - though it did not come easy to some. The person cooking breakfast was always first up (before $6.00 \mathrm{a.m}$.) and porridge was the main course to begin each day. Everyone took this willingly - there wasn't much choice anyway! Although this did not make for the most exciting start to each day, it was adequate and we were normally ready to start the day's activities by 8.00 a.m.

When the weather was fine and the mountain clear of cloud-which it was on only about one day in four - the majority would take the West Road inland, others make off along the beach, in twos and threes, having equipped themselves with packed lunches. These usually consisted of sandwiches with a quantity of cheese or tinned meat, and a ration of Kendal mint cake, a Lion Bar or other chocolate delight, plus the inevitable chewing gum and beef cubes.

Whether ascending the mountain or walking along the boulder beach, the going was never easy. First, there was the dreaded tussock to get through: Often over six feet high, densely-growing and with rough leaves plus sharp stalks when broken, it made progress a battle. Even where a path had been made through it previously, this often needed to be opened up again. Then there was the steepness of the climb for those going inland -430 metres to the escarpment in a horizontal distance of $1 / 2 \mathrm{~km}$. Or, on the beach, the rough rounded boulders were never stable and one had to be wary of losing one's balance at every step. So, whether going up or along, it was tough; but we got used to it. Though we never became as agile as the Islanders, a record of 34 minutes was held by lan for the ascent. Most of us took much longer, but all reached the Base in less than an hour. Once up there and after a welcome rest among some grotesque rocky outcrops looking like outsize tombstones, each group of us set off in an appropriate direction for the day's work.

Walking on top wasn't easy either: The vegetation was always at least knee-high and the soft ground was honeycombed with birds' nest-burrows into which one all too easily fell through. In parts, there was dense Phylica (Island tree) forest which could be well-nigh impenetrable. The best walking was near the edge of the escarpment, but that was always next to a nearvertical drop! So, you needed to know your bearings, especially as the cloud could descend in a few minutes without warning.

The plateau of Inaccessible is more undulating than rugged, so there are few places of shelter from the wind which could blow ferociously at times. On the infrequent occassions when the weather was really fine, it was idyllic up there with a spectacular view of Tristan $40 \mathrm{~km}$ away, towering out of the haze or cloud to a height of $2,080 \mathrm{~m}$. By contrast, to the East you looked down on to smaller Nightingale Island at half the distance. In such surroundings and with so much to do, time slipped by and it was, as often as not, the 
thought of food which reminded one it was time to go down that steep pathway again. Most of us took the descent slowly, but there was a record for that too- of 11 minutes 6 seconds!

Back at the hut, we would exchange news and work up the day's data or collections, perhaps in our small lab., while supper was being prepared After our fairly basic, but always ample meal, we tended to relax, write-up the Expedition-or personal log and, as it was by now dark, turn-in early, duly tired. Our Tilley lights-out was seldom after 10.00 p.m., the exceptions being on 'bird' nights when the mist was down and we put the Tilleys outside to attract the 'nightbirds' like so many moths. Then our beauty sleep would be disturbed by thuds as the birds flew into the walls and by the trampling of human feet back and forth to the lab. with accompanying dictation of bird measurements - a veritable biometric lullaby.

\section{COOKING}

The best food we ate on Inaccessible was what we caught and trapped, together with the Tristan potatoes. The dehydrated meat and the meat in tins supplied by various well-known companies were greeted with such disdain from the whole expedition that one prayed for the day when one knew that our Island guides were fishing, or that one had a back-up of dead Shearwaters from the previous day, even though both meals demanded a considerable amount of preparation.

The "Five-Finger," the only fish which could be caught from the shingle apart from the almost inedible "Beva" or "Soldier-fish," was shaped rather like a Perch, though it ranged in size from small Lemon Sole to large Turbot. Nelson and Andrew taught me their filleting method which produced fillets without bones which could be fried "Meuniére" and which everybody ate for as long as I could go on cooking. Following a good fishing day, I could produce a fish-pie in a plastic bucket on the next day, aided by judicious use of potato powder, which meant that the whole meal was really hot because potato powder could only be made-up in exact quantities with boiling water at the last minute.

The basic breakfast was tea and porridge (the last time I had eaten porridge was as a junior member of Woodard House in 1951-52-then, as now, the alternative was starvation); the basic lunch was cheese, biscuits or bread, beef tea, and a chocolate/sweet biscuit of some kind, though during the brief Shearwater egg season, lunch was sometimes enlivened by surplus eggs. Conservationists may wring their hands with horror, but we ate about two hundred Shearwater eggs during a two week period and something like four hundred Shearwaters during the time I was on the Island (the population in the vicinity probably exceeded a million pairs). The eggs were extremely nutritious, being about three times the size of a hen egg, and were good hard-boiled, scrambled, fried and in omelettes - they also enabled me to make fish-cakes on one occasion-somewhat amorphous fish-cakes but greatly appreciated because on that day there was actually a main course to follow!

I had to be guided by Nelson and Andrew in the preparation of the Shearwaters which, like the eggs, had been an essential component of the Tristan Islanders' diet presumably since the days of Corporal Glass, though I imagine that the Inaccessible population must have increased to the million which we estimated in 1982 since 1816 . Having got the idea the first time that twenty-four dead Shearwaters were sprung on me at $5.45 \mathrm{p} . \mathrm{m}$. with instructions to "cook 'em for supper," and having got by on that occasion through the judicious use of curry powder, I consulted Miss Jocasta Innes' "Pauper's Cook Book" (an invaluable aid) and her recipe for "Rabbit Marengo" on page 63 of the Penguin edition. (Our other cook book, also very useful, Miss Bee Nilson's "Penguin Cookery Book," unfortunately contained not a single recipe for penguins, an astonishing omission.) To return to Rabbit Marengo, converted into Innaccessibalese, "Shearwater Marengo" ran something like this:

Ingredients: 24 Shearwaters (assorted ages) cut into small pieces, vegetable cooking oil, powdered garlic, Cape "Mixed Herbs," half a $7 \mathrm{lb}$. tin of peeled tomatoes with juice, $4 \mathrm{oz}$. concentrated dehydrated mushroom soup, 1 pint hot water, salt, pepper, 1 tin of butter, juice of two tired oranges, $4 \mathrm{oz}$. dehydrated sliced French beans.

Method; Fry Shearwater meat in oil until brown, transfer meat to plastic bucket. Divide oil between large saucepans. Add liberal dessert-spoonfuls of "Mixed Herbs" and half the tomatoes plus juice. Several dessert-spoonfuls of butter change the consistency of the sauce, as does the "mashing" of the tomatoes with a fork. Put the mushroom concentrate in a measuring jug and add the hot water; mix. Divide the mixture between the two saucepans, adding salt, pepper and the juice of one tired orange to each. Take saucepans off the rings in case the contents burn. Throw French beans into small saucepan and add hot water until they swell to normal size. Divide meat between two big saucepans and return to rings for "moderate" cooking - as the rings produce heat only at full blast, stir frequently. Add French beans ten minutes before serving. Pour ladlefuls of Shearwater Marengo into messtin of client, who has already placed therein his regulation three cold boiled peeled potatoes, chosen from adjoining plastic bucket.

Nick had given great thought to the cooking of bread prior to our departure and it was frustrating that the absence of an oven made depredations on the supply of cheese crackers excessive during the first ten days on the island because we had good supplies of flour. Then lan converted an empty paraffin tin into an oven, heated by two Primus stoves (which needed relighting every forty-five minutes) and this made a continuous bread supply possible because 
Nick taught all the younger members how to make bread. The younger members then learnt very quickly how to make cake by themselves.

I have no space here to record the menu nor the events during the dinner party for Andrew's birthday on the 27th of November: the amount of food prepared was three or four times the normal quantity and was three or four times as rich, and as it all disappeared down eleven gullets (Gilfie was ill), I had cause to reflect on the restraint which had been exercised during the previous six weeks, particularly on the part of the ravenous young.

Perhaps three extracts from my diary sum up the basic monotony of the situation, if not from the point of view of the consumer, at least from the point of view of the cook. On the 14th of November I wrote:

"One of the things that slows life down is the fact that every drop of water has to be carried over a hundred yards. Every pint of milk has to be made from powder, every five hours the paraffin has to be filled up in the cooker and every two hours the paraffin has to be filled up in the Tilley lamps. No electric light because the Wind Generator isn't powerful enough. No heat, so if things get wet, we have to wait for the sun to dry them."

On the 1st of November there are two extracts; the first reads:

"I know now why Sylvie (my wife) gets so angry when I ask her what is for dinner three or four hours in advance-cooking for twelve is a very salutary experience!"

The second reads:

"After this trip all members of the Expedition are going to come and stay with us in Yorkshire, if only to prove that given proper equipment, I CAN cook!"'

\section{MEDICAL MATTERS}

A tremendous amount has been written about the job of "Expedition Doctor," but little of this has any relevance to temperate mid-oceanic islands. The level of equipment you take to such places supposedly depends on how close you will be to the nearest continental medical facilities; but I now realise that distance is of no relevance if the ocean between is deep and nearly always stormy! So, I had originally made up a list which would have equipped a small hospital but, for a variety of reasons, rationalised this to just one packing case. This contained enough stores for forseeable minor illnesses and to last for a few days 'First Aid' in case of major problems. Early evacuation to Tristan da Cunha was assumed.
Long before we set off, but after selection, Team members were asked to complete a questionnaire as a record of past illnesses and present fitness. I would have been happy to have had people with chronic illness, provided they were known and planned for. The School Doctor (Michael Woodhead) kindly examined members at Denstone, but found nothing untoward. Dental check-ups were provided by the School Dentist (Bard Taylor). Those who wore glasses were advised to take at least two pairs. All of us received innoculations against tetanus and polio; no others were considered necessary. Medical supplies were provided almost entirely through the generosity of the pharmaceutical industry, some bought specially and I provided the rest.

Apart from one wasp sting in South Africa, illness on the journey was confined to sea-sickness which was anticipated and for which the necessary tablets were prescribed most effectively. Once on Inaccessible, only one member became ill, complaining of abdominal symptons including complete loss of appetite - a most unusual indicator amongst a group of fit young men! This illness cleared up very soon after crossing to Tristan without any specific treatment. Sunburn was a common risk on bright days, but Sunscreen was freely available and we had only one complication, a secondary infection of the nose which was treated with anti-biotic. Minor injuries such as cuts, grazes, sprains, fish-hook wounds, albatross and shearwater bites were few and easily dealt with. There were no infections of minor wounds, even without special precautions.

We went prepared to sterilize all our drinking water. In the event, this proved unnecessary. Although most of the water on Inaccessible is brackish as it drains off peat, there is one major stream originating from a spring, close to where Nelson advised us to site the hut, that is perfect for drinking. A number of curious organisms were found in this by our invertebrate zoologist, but we took no harm from them. A few purification tablets were used by survey groups camping overnight on the plateau; but these made the water taste worse and were soon given up with no harmful effect.

The choice of foodstuffs was not my responsibility. I did however ask for wholewheat flour to be included. Our diet, based on porridge, wholemeal bread and potatoes provided a considerable increase in dietary fibre for most of us, resulting in a queue every morning for the "seat on the beach" and no complaints of constipation. 


\section{THE WEATHER}

The climate of Inaccessible Island had euphemistically been described as 'mild oceanic.' Before we set off, the description 'rather like the Lake District in Summer' had also been used, optimistically implying 'warm, wet and windy.' What we actually experienced exceeded all expectations!

Knowing the Tristan Group to be situated on the edge of the Roaring Forties, we expected it to be windy; in viev of its isolated position in the midSouth Atlantic, we expected it to rain too but, what none of us could anticipate, was what turned out to be the worst Spring and early Summer these islands had experienced for twenty years.

Our first experience, at Gough, was of low cloud which hung over the islands most of the time. On Inaccessible, we got used to it limiting our activities three days out of every four. What was always likely to catch us out was the rapidity with which the cloud descended on the Island - in a few minutes and apparently coming from nowhere-with an accompanying sharp drop in temperature and increase in wind speed.

Somehow, we were not greatly alarmed by the strength of the wind; but we were taken unawares at times by its ability to gust violently - a disturbing experience when one was half way up a cliff. At times, however, it could be severe, as when it threatened to blow down the end wall of the hut or whipped off the roofing felt at one go. Its effect on the sea was also dramatic and it was fascinating to watch the blown spray leaving the top of the great rollers as they broke over Blenden Hall reef. The rapidity with which the wind direction could change was also impressive and we soon learnt to appreciate the Islanders' caution of the weather because of this, especially before launching our rowing boat.

Rain there was in plenty $-2 \frac{1}{2}$ inches in one night was not abnormaland it had a disconcerting habit of coming through the roof of the hut. We usually succeeded in catching it in an array of mess tins which, together, gave a symphonic rendering through the night; but it often found its way into one's clothing as well. On some occasions, the only way to avoid being soaked and to ensure getting some rest for those in the notorious wet spots in the hut, was to sleep under the table - at least there one got the sensation of being in the orchestra. Drying-out our clothes afterwards was not a problem however, with such good winds to hang them out in; but drying scientific specimens on the other hand became a nightmare.

As the rain and wind normally came together, conditions were frequently hardly ideal for camping and there was more than one occasion when the occupants of a tent spent the night sitting holding onto the tent poles. Indeed, so violent was the storm once, that the poles (tested in the Himalayas) just buckled and the camp had to be abandoned.

When the bad weather continued for days on end, the effect was a little demoralising and the resulting frustration of our being cooped up in the hut was noticeable, though never serious. However, after the party's return from Tristan, the weather pattern changed and there were some really hot days, especially at Blenden Hall which was then free of wind. There was a high risk of sunburn, though we had a good supply of the appropriate lotion. It was however salutary to realise that, on one particular day, the temperature we measured in the hut was $30^{\circ} \mathrm{C}$ warmer than it was reported on the radio to be at home.

So we are no longer prepared to describe the weather on Inaccessible quite so glibly. Perhaps such words as 'unpredictable,' 'unreliable,' at times 'violent,' even 'extreme' would be appropriate; but, at least it always gave us something to talk about-quite like home really. Naturally, we kept daily records of the main weather factors and these are among the Expedition's data.

\section{SHIPWRECKS OF INACCESSIBLE ISLAND}

Throughout the last century the volume of shipping circumnavigating the world with the aid of the Trade winds in the Southern Oceans was immense.

The islands, such as Tristan da Cunha, which lie in these seas were often used as navigational aids or were visited for water and much needed fresh food. Since the mariners were totally at the mercy of the elements it is no surprise to learn that many ships were lost and wrecked on such islands, often being swept helplessly on to reefs by strong currents or happening on uncharted rocks in poor visibility.

The Tristan da Cunha group has the dubious honour of having claimed at least twenty-two ships and, in past times, the islanders have used the wreckage from ships to furnish their homes; two houses still proudly possess the name plaques of the barque 'Mabel Clark,' which foundered on the main island in 1878.

Three ships are known to have been wrecked on Inaccessible, the Helen S. Lea off north point in 1897, the Shakespeare off Pig Beach in 1883 and the Blenden Hall which gives its name to the western part of the island where it was wrecked and is also the site of the Expedition Base Camp. The story of the disaster and the subsequent adventures of the survivors is fascinating and makes a major contribution towards the early history of Tristan.

Much of the story still remains a mystery but we can thank J. G. Lockhart for the fullest account of the tragedy in his book entitled 'Blenden Hall' published in 1930. He in turn uses as his main source the account of Alexander Greig, a passenger on the ship who was also the captain's son. The reason 
for the lack of knowledge and the delay in the publication of the final story appears to be as a result of the incidents surrounding the wreck, the time on Inaccessible Island and later on Tristan, which show many of the passengers and crew to have been very dishonourable characters.

For much of the time on Inaccessible there was continuous arguing and fighting, to such an extent that there were two separate camps on the Island both of them being hostile towards the other. For this reason, on their return to civilization, most of the people involved saw it to be in their best interests not to say much about it and indeed, in his account, Alexander Greig alters the names of the participants.

The Blenden Hall a ship of 450 tons was built in Southampton in 1811 and was owned by Captain Greig. It was chartered to the East India Company and although she sailed between Britain and India she was not a purposebuilt Indiaman. The voyages to India were dangerous, especially during times of war and, for this reason, the ship was armed and had a large crew far beyond the numbers needed to work the ship.

She sailed from Gravesend on the 6th May, 1821 and much of Lockart's narrative of the voyage centres upon the continuous quarrelling amongst the passengers. They made fairly good progress across the Bay of Biscay down to Tenerife but they were becalmed for up to three weeks as they neared the Equator.

Having crossed the Equator the ship was carried by a current rather nearer to the coast of South America than to that of Africa. To reach the Cape of Good Hope she therefore had to set a S.W. course past St. Helena. As time went on she was again swept off course by large westerly currents so that by mid July she was very close to the Tristan da Cunha group of islands.

The ship ran on to a reef off Inaccessible Island at 10 a.m. on the $22 \mathrm{nd}$ July in calm seas, the only apparent reason for the mishap was that it was a very misty morning. The Captain must bear some of the responsibility for allowing his ship to come in very close to what he thought was Tristan da Cunha. The ship's back was broken and the people on board waited for what seemed like certain death. By an apparent miracle however, when the forecastle on which all the survivors were huddled broke away from the main wreck, it was carried inshore and all but two of the eighty-four passengers and crew were saved.

They were now in a terrible situation, very cold and hungry, some of them naked and with no obvious shelter. The way they spent the next months is a fine example of all that is rotten in human nature; they argued, fought, stole, drunk and behaved, with a few notable exceptions, in a terrible manner. That they might act in such a way we should perhaps not condemn-who can say how we would react in such hopeless circumstances?
After a short while it became obvious to them that they were on an uninhabited island, not Tristan, and that surviving was going to be a tall order. They were lucky in that they had a reasonable supply of fresh water and a large supply of wild celery, seals and penguins. These combined with the few supplies that were swept ashore from the ship made up their diet.

Following various sorties onto the plateau of the island they could estimate the distance to Tristan and they realized their only means of survival was to get there. To this end, some of them began building boats; that many small boat-building teams set to work is yet more evidence of the lack of unity within the group. The first boat to make a serious attempt to cross the 27 mile stretch was the one made by the cook and five other seamen. They failed to get there, and were never heard of again.

Later, another boat managed to make the journey and, on the 10th November, boats arrived at Inaccessible from Tristan to rescue them. They were taken back to Tristan where they quite overwhelmed the population of eight people. Here too the survivors from the Blenden Hall behaved in a most disagreeable manner and it was a great relief to Corporal Glass, the Governor of the small population, when all but seven of the survivors were taken off Tristan on the brig 'Nerinae' which took them to Cape Town.

With this adventurous tale as a foretaste, the prospect of finding signs of the Blenden Hall on Inaccessible Island was quite exciting and we were not disappointed. At two sites we found quite extensive wooden spars many containing large nails; however the ultimatic relic, the name plaque was nowhere to be found.

Another very exciting find was a metal capstan, presumably from a more modern ship the identity of which at the moment is uncertain, though various ideas are being followed up. 


\section{BOTANY}

The 1979 edition of the 'O.D. Chronicle' arrived as others have before and since. I usually read them on the day of arrival and they then go to collect dust with the others. On this occasion, after the account of a disappointing O.D. Athletics match, I found a few paragraphs about a proposed Expedition to Inaccessible Island. I contacted Mike Swales immediately and offered my services as Medical Officer. The answer was simple: "We've got one, but you know a bit about plants, you can be the Botanist! Think about it." I read a bit about it and agreed.

The Botany of mid-oceanic islands is simple in some ways: Most of the native species present are lower plants (ferns, mosses and liverworts) because these produce spores rather than seeds. Spores are extremely small and able to travel long distances on the wind, so colonisation of a new volcanic island is easier for them than for higher plants with their heavy seeds. Those higher plants which are native to Inaccessible Island do not require colourful flowers: There are no bees to attract. This means that the general colour of the vegetation is a mixture of shades of green.

Little previous work had been done on the vegetation of Inaccessible Island, although Tristan itself has been well covered; so much could be inferred. So, knowing roughly what to expect, my first aim was to make a complete collection of botanical specimens and then, in any time left over, try to do some quantitative studies of the various plant communities. Without an accurate map to work from in the field, it is impossible to randomize sample sites for this; our map was not yet made, so these had to be selected.

Good collections had previously been made at West Point, Blenden Hall, Salt Beach and Waterfall Beach. Few specimens had been taken from the plateau because of the difficulty of access. Alien species (mostly thought of as 'weeds') are usually ubiquitous; on Inaccessible they were mainly recorded from the Waterfall area as this was the site of huts previously used by fishermen and Islanders. I did not find many and this led me to wonder if they are dying out there; potatoes, however, have naturalised well, though turnips seem to have reverted to the wild type.

The cliffs and coastal slopes are dominated by tussock grass which can be a rampant grower, growing to well over two metres tall in the right conditions. The main plateau can be divided into three vegetational areas. The southern part, with prevailing southerly winds, is dominated by waist-high tussock with a higher proportion of other species growing among it than on the cliffs - particularly conspicuous are the flowers of the Island celery. The most sheltered area is in the northeast, dominated by the Island tree (Phylica) which reaches a height of four metres, with many ferns growing beneath it. In between these areas is one of gradual change from forest to fernbush to tussock grassiand. The fernbush is dominated by the tree fern Blechnum palmiforme which grows to two metres in height and looks, as its name suggests, like a small palm tree. The fernbush covers the higher ground in the West particularly; but this may be changing, as Nelson told us that the amount of tussock had increased noticeably since he had last seen it.

There are at least three types of peat bog on the Island. The most dramatic is Skua Bog at West Point whose surface is a floating carpet of club rush which will just support a person. The upland bogs are of two kinds: Those dominated by Sphagnum moss in the valleys, and those at the origins of streams in the fernbush which are covered in club rushes. Special collections were made of peat samples from Skua Bog and from one of the upland Sphagnum bogs, using a Hiller borer. These will be subjected to radio carbon dating and pollen analysis.

Other botanical work included making a collection of marine plants from the rock pools at Blenden Hall Beach. Here, the zonation of seaweeds is compressed because the Spring tide fall is only two feet. Lichens were also collected-over 50 specimens in all-a considerable increase over the previous tally of four. 


\section{THE SURVEY}

One of the most important tasks for the Expedition was to produce a shore based map of the island because, prior to October 1982, no such map existed.

Following the withdrawal of Adrian Wareham in the Summer 1982, Clive Siddall became specialist surveyor and, in order that he might become familiar with the required techniques, he attended the R.G.S. Expeditions Surverying course. Throughout the duration of the Expedition he was assisted by Jonathan Dakin, although all the team members contributed to the survey work in some way.

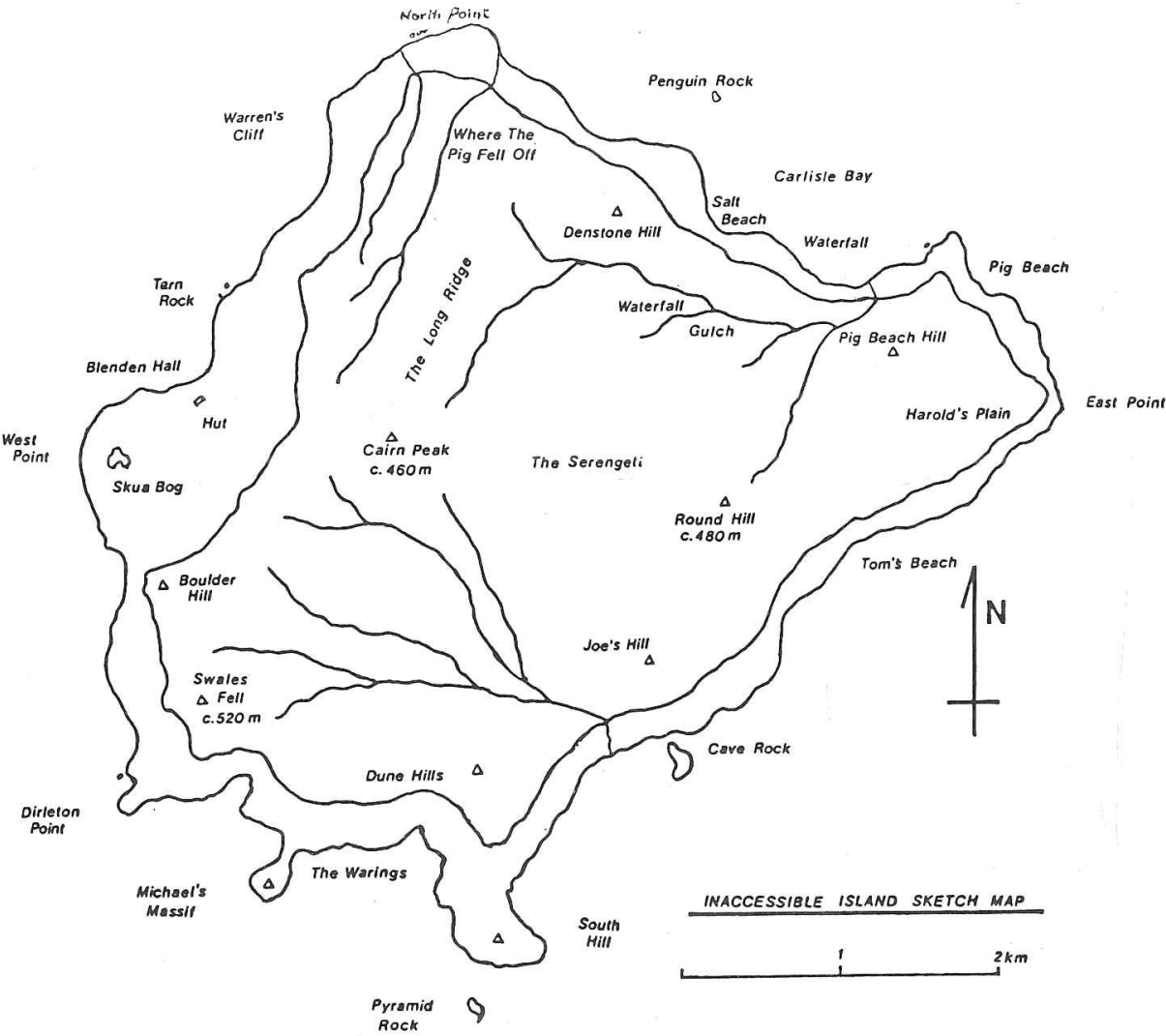

(For full-size large scale Final Map, see inside rear cover)
The principal aims were:

(1) To produce a 1:10,000 scale map of the whole island.

(2) To produce several larger scale maps to assist other specialists in their work.

(3) To determine the longitude and latitude of a point on the island as accurately as possible.

These projects were carried out using the surveying equipment belonging to the College, although this nearly proved to be a serious mistake as the theodolite was damaged on arrival in South Africa. However it was repaired at Cape Town University.

Following an initial walk around the plateau of the island it was decided to map it in two distinct portions, North and South, with some coincident major controls. One base line in each sector was measured and a large number of major controls were established and triangulated, other sub-controls were triangulated in the less accessible regions. The details were infilled using theodolite and, whenever possible, plane table. A sea level datum was established and, using Indian clinometer and theodolite, the heights of the summit of the island (Swales Fell) and the principal height datum (Cairn Peak) were calculated. Many spot heights were obtained and from these contours were interpolated. The map was orientated using a trough compass.

The Blenden Hall area was surveyed at 1:5,000 using plane table methods and this map was incorporated into the map of the whole island at the smalle scale.

Two more coastal areas were surveyed at 1:5,000 using the plane table, and several other surveys and profiles were carried out using the methods of offsets and levelling respectively, to assist other specialists in their work. The whole island was systematically photographed to assist the survey work.

The surveyors faced many problems posed principally by the climate, terrain and vegetation. The cloud cover, wind and rain limited survey work to two days in every five on average and the steep gradient of the cliffs, combined with the dense vegetation, tended to make movement very slow.

The position of South Hill was determined, using sextant in conjunction with land survey data and the satellite navigational equipment of the M.V. 'S.A. Agulhas.'

Nightingale and Tristan Islands were triangulated from Inaccessible using the theodolite.

The surveyors appreciate that much work remains to be done to bring the map of Inaccessible to a truly acceptable standard and it is their hope that this can be achieved as soon as possible, perhaps with the aid of aerial photography. 


\section{PHILATELIC FACTS}

The Post Office opened on the Island on 25th October, 1982 (=26th in Australia) and it closed on 9th February 1983 which was the last day of franking. Covers were prepared intermittently between these dates, but the First (and only) Official Collection left Inaccessible Island on 10th February, 1983 in H.M.S. 'Endurance.'

The total number of covers serviced on Inaccessible Island was 6,500 . Stamps were cancelled using the official Post Office date-stamp, supplied and designed by the Crown Agents, and bearing the legend 'Denstone Expedition to Inaccessible Island' below a crested penguin standing on an island. It was used only at Inaccessible Island.

Tristan da Cunha stamps were used, purchased previously from the Post Office there and including: 5p Royal Wedding, 5p Old Map, 5p Duke of Edinburgh Award and 5p Volcano; 10p bird stamp; sets of four Inaccessible Island Rail, Volcano and Princess of Wales $21 \mathrm{st}$ Birthday commemorative; and complete set of bird definitives. Three sizes of envelopes were used, some printed with the Expedition logo, others bearing the Expedition cachet; only the latter are marked First Official Mail.

The Postmaster, appointed by the Administrator of Tristan, was Dr. Nick Hall and he was assisted by Richard Holt.

\section{THE TEMPORARY POST OFFICE}

Inaccessible Island, the second largest in the Tristan da Cunha group in the South Atlantic, was the destination of the Denstone Expedition to Inaccessible whose objectives were to carry out the first scientific exploration and shore-based mapping of this remote Island. The Expedition was given permission to open a temporary Post Office on the Island for the duration of our time on Inaccessible. We used an official Post Office date-stamp which was specially supplied and designed by the Crown Agents and bore the legend "Denstone Expedition to Inaccessible Island" below a crested penguin standing on an island.

Dr. Nick Hall, who was the Expedition co-leader, doctor and botanist, was appointed as Postmaster by the Administrator of Tristan, Mr. Colin Redston, during our outward voyage to Inaccessible and Mike Swales, the Expedition leader, appointed me Nick's assistant. It was my responsibility to keep records of the orders and of the numbers of covers produced. Originally, we had intended to produce only three types: A $5 p$ single stamp cover, for which we chose the Royal Wedding stamp, a set of four Inaccessible Island Rail stamps and the complete set of bird definitives. However, when we saw the diversity of Tristan stamps, we decided to buy others. So, in addition, we bought 100 of the $5 p$ Old Map stamps and 500 of the $5 p$ Duke of Edinburgh Award Scheme stamps which quite appropriately represented the expedition aspect of that Award. Also, we bought 100 of the Volcano sets to make our only First Day Cover on the day of their release, November 1st, 1982.

We landed on Inaccessible Island on 16th October, 1982 and, for the first week, we were occupied in building our hut and generally orientating ourselves. Our first wet day, once we had settled in, was October 25 th when the Post Office opened for the first time. We nearly had disaster befall us when we discovered that damp had got into our mail bag. Fortunately, the damage was not as bad as originally feared - the majority of the $f 1,000$ worth of stamps were totally unaffected, much to our relief. However, some were damp and had to be pinned by the edging to the walls to dry. The damaged stamps were retained for our own personal letters.

We had three sizes of envelope, some printed with the Expedition logo designed by Jonathan Cooke of Denstone College, and others bearing the Expedition cachet designed by Mike Swales. At first, the latter proved difficult to use: If too little pressure was applied, the cachet would not come out, if too much it would smudge. Also, the pressure had to be applied in the middle or the cachet appeared uneven. At first, we were wasting one in two envelopes. We had originally planned to have a production line-one person applying the cachet, another tearing the stamp perforations, another sticking the stamps on and lastly one cancelling them. However, this plan was abandoned for two reasons: First, the processes took very different times and, second, the lack of bench space. The tearing proved tedious, as it necessitated three folds to make sure the stamps were not torn. Even after this precaution, a number were damaged and were kept for our own letters. The sticking was quite a skilled job: It required precision to put the stamp on straight without smudging the glue, resulting in dirty marks around the edge. The sets were hard to arrange as the spaces had to be organised correctly - the definitive set on one envelope proved to be a nightmare. It was necessary to wash our hands regularly as they became sticky very quickly. Franking was the most rewarding operation as it signalled the finished product. I felt a great sense of achievement when I had successfully aligned the frank and produced our first $5 p$ Royal Wedding Cover.

The whole process was repetitious but, at the same time, rewarding. I felt satisfied each time we had produced another 500 covers; but I looked forward to finishing the whole lot. So you can imagine my dismay when Mike Swales bought approximately another 1,000 stamps on Tristan, including the Princess of Wales 21 st Birthday Commemorative set, to keep me in business when we returned to Inaccessible after spending Christmas on Tristan, during which time 'our' Post Office was closed. 
The Post Office meant we had a useful way of spending our many wet days; but, because the covers required a great deal of concentration, it was only open for three hours at most on any one day. We were grateful to have brought two personal stereo head sets with us, which made the work much more pleasant. We had to protect the covers and stamps with plastic bags at all times from the frequent leaks in our hut, until the official collection by H.M.S. 'Endurance' on February 10th, 1983. Another cause of anxiety occurred concerning the Volcano set: Having franked them all on November $1 \mathrm{st}, 1982$, an argument ensued disputing the first day of issue. This was however resolved in our next radio schedule with Tristan, when I breathed a sigh of relief on hearing that I was right.

During our stay on Tristan over Christmas, the minimum postage rate was increased from $5 p$ to $10 p$; so, all our basic covers became $10 p$ ones, using the $10 p$ bird stamp after we returned to Inaccessible on January 21 st, 1983 The Post Office closed finally on February 9th, 1983, which was the last day of franking, and we used up the last stamps for personal letters. The date stamp was then taken to Tristan and withdrawn. I felt very sad as I cancelled my last stamp, thus ending my reign as Postmaster's Assistant, during which time we had produced 6,500 covers. I had become so accustomed to my job that, when I came home, it felt very strange to have to post an uncancelled letter!

\section{GEOLOGY}

The Denstone Expedition to Inaccessible was not the first to land a geologist there; the Norwegian Scientific Expedition to Tristan da Cunha landed a South African geologist, J. C. Dunne, on the island for a three week period during January 1937. During the eruption of the volcano on the main island of Tristan, another expedition, from England, made a brief visit to the west end of the island. The three weeks that Dunne spent on the island were sufficient for him to create a sketch geological map of the island, and $P$. Baker managed, in 1962, to verify some aspects of the geology.

Although the Denstone Expedition was active on Inaccessible for severa months, I was only able to spend three weeks there, just as Dunne had done some 45 years earlier. However, I had the advantage that other expedition members had scouted out the island so that I could approach the most interesting areas quickly.

Futhermore, I had some form of a map with which to start surveying from the outset. Even under these conditions, three weeks was not sufficient to completely survey the island, especially considering the vagaries of the weather.

Upon arrival, my approach to studying the geology was to try and take as many samples as possible and photograph all geological features of interest, ensuring a maximum amount of data for future researchers. The weather and terrain did not enable me to inspect every part of the island and time did not permit me to visit every outcrop, but I did manage to visit and sample from areas not previously studied by geologists.

Inaccessible is a remnant of a volcanic cone lying on the ocean floor some $3,000 \mathrm{~m}$ below the surface of the sea. It is surrounded by steep cliffs, mostly sheer, the highest, some $400 \mathrm{~m}$, being on the west and north sides, and the lowest, about $70 \mathrm{~m}$ being on the east side. The top of the island is quite heavily dissected by three drainage systems, the smallest at the extreme north west part of the island, the next largest occurring along the eastern part of the north coast, and the main drainage system occupying the major portion of the centre and western parts of the island (the total length of the combined major streams in each system is $2 \mathrm{~km}, 3.2 \mathrm{~km}$ and $4.7 \mathrm{~km}$, respectively). Outcrops are few on the plateau, occurring only where streams have cut through the lava flows; the surface is otherwise mainly peat.

The cliffs and shorelines are the most dynamic parts of the island due to the nature of the sea and weather: the rate of weathering of the exposed rock faces is high, and weathering products are quickly transported away by frequent gales. Slumping appears to be common and, during heavy rain, small particles continually fall from the cliff-faces. The cliff section immediately to the north of Blenden Hall appears to have slid down some $70 \mathrm{~m}$ on a scale too large to attribute to weathering; this might be evidence for an earthquake on the island. 


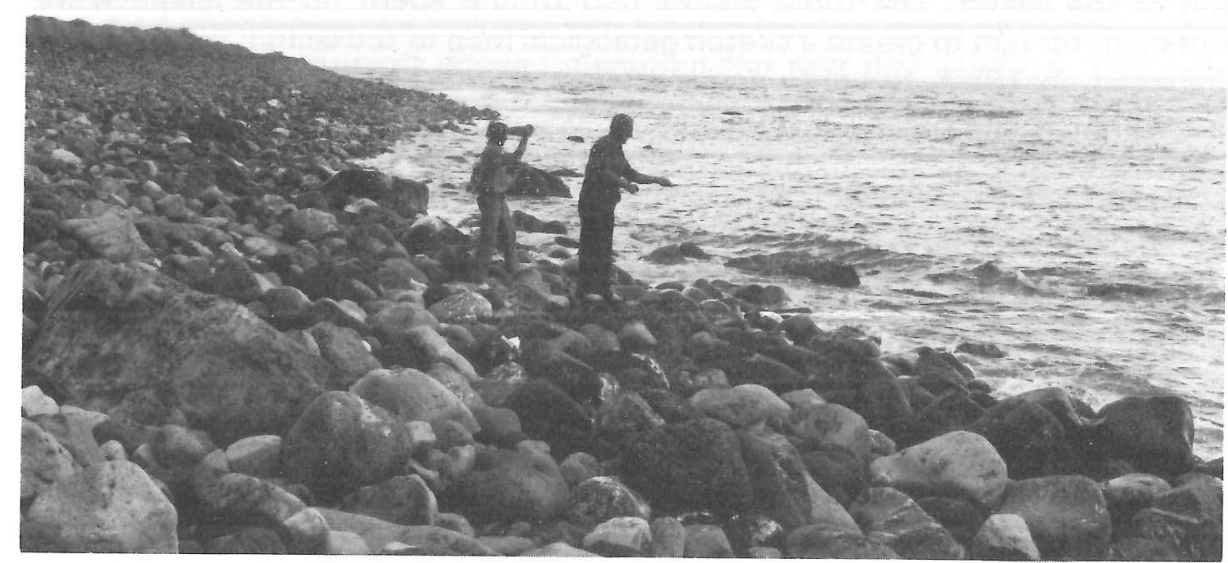

The treacherous boulder beach at Blenden Hall with Islanders fishing.

The shoreline is a product of the cliff-slumping, particularly along the north-east coast, and the action of the sea throwing material up during storms. The west coast, West Point and Blenden Hall, would appear to be products of this latter action, not unreasonable since it faces the full brunt of the winter storms coming mainly from the south-west. West Point is a large platform, the centre of which contains a peat bog which appears to be floating on water which in turn overlies an old pebble beach. The seaward side of the platform is a modern pebble beach comprising four distinct benches on the seaward side, each indicating erosive action during storms of given degrees of severeness. The very presence of the platform forming West Point is of interest in that it may be good evidence that a change in sea-level of about $5 \mathrm{~m}$ would be sufficient to form a pebble beach at this locality. Further evidence of a higher sea-level is rare, largely due to the extensive slumping from the cliffs covering the evidence. There is a cave at Warren's Cliff in which logs have been embedded into some infill material above sea-level which may indicate that a beach deposit might have existed there prior to the recent erosion forming the present cliffs. These, and other indications of a higher sea-level, are reflections of the melting of the ice caps some 10,000 years ago.

Inaccessible is purely volcanic and would appear to have formed around 5 million years (Mys) ago, thus making the island middle in age of the three islands in the Tristan Group (Nightingale is approximately 18 Mys old, and
Tristan is around 1 Mys old). The main components of the island are the basalt lava flows interbedded with the pyroclastic material. These flows dip gently to the east throughout the whole island, indicating that the volcanic centre of the island lay somewhere to the west of the present island; that is, only the eastern half of the island remains today. Further, the sub-surface soundings show a large shallow region extending westwards from West Point, thus possibly outlining the original extent of the island.

The west and south-western part of the island contain intruded masses of trachyte forming the dramatic backdrop to West Point, and South Hill and Michael's Massif. These are structures that were injected into the active volcano, but which never reached the surface, until subsequent weathering had exposed them. Along the cliffs of the south-western part of the island, dykes and sills of this same material can be seen originating from these intrusions.

Although the main vent of the original volcano was responsible for the main lava sequence, numerous parasitic centres were actively producing pyroclastic material (e.g. ashes and agglomerates) which now are found around the edges of the island. The main such centre lies immediately north of Blenden Hall where the cliffs have a yellowish appearance from the weathered ashes.

On the eastern part of the island plateau, there are a number of surface cinder cones, the most dramatic being Round Hill which has still kept its origina form (complete with a breached east side). It would appear that Denstone Hill, Pig Beach Hill and Joe's Hill are of the same origin, but these have yet to be confirmed by sample analyses.

Throughout the earlier phase of the building of Inaccessible, dykes were being emplaced with great frequency mainly in a north-easterly direction, and are of similar composition to the main lavas.

Inaccessible Island is midway in age and erosional state of the three Tristan Islands. Although there is a deep water separating the three islands, there is obviously some genetic relationship between them. It appears that this isolated area has given rise to volcanic activity at $18 \mathrm{Mys}, 5$ Mys, and 1 Mys ago and as late as 1962 (the 1962 vent is still very warm indicating the presence of a magma not too far below the surface). What is the reason for the existence of this group?

The Tristan Group is one of a number of oceanic islands that lie close to the Mid-Atlantic Ridge, a long mountain chain running the entire length of the central Atlantic Ocean. New oceanic crust is being formed along this ridge and, as further crustal material is produced, the crust is gradually pushed away from the ridge. The ocean floor is thus older the farther it is from the ridge. This action of sea-floor spreading moves very slowly, about 3 to $5 \mathrm{~cm}$ per year on each side (therefore, South America and Africa are being pushed apart at about 6 to $9 \mathrm{~cm}$ per year). We do not know the constancy of this rate, 
but evidence suggests regularity. The Tristan Group is approximately $48,300,000 \mathrm{~cm}$ from the Mid-Atlantic Ridge, depending on where you measure from. At the rate of $2-3 \mathrm{~cm}$ per year, we find that Nightingale Island must have been above the Mid-Atlantic Ridge when it was being formed. But why did volcanism see fit to erupt into this enormous mound at this particular point? At various points along these mid-ocean ridges, 'hot-spots' of some form occur and disrupt the normal spreading process; Iceland and Hawaii are classic examples of this, but in both instances, the 'hot spot' remains stationary while the ocean crust moves above it causing the volcano to grow (Iceland) or, if the activity is intermittent, causing a series of smaller volcanoes (Hawaii).

Clearly the Tristan Group is not quite the same: since volcanic activity is still present, the 'hot spot' has moved with the islands. The nature of 'hot spots' is controversial, even to the point where some specialists doubt their existence. Centres such as Hawaii and Iceland have been intensively studied but the slightly anomalous situations like the Tristan Islands have, for obvious reasons, not been subject to such through studies. Thus, additional samples for chemical analysis and dating from Inaccessible may help us to understand the nature of volcanism forming these isolated islands.

\section{INVERTEBRATE ZOOLOGY}

Oceanic Islands have always held a fascination for biologists ever since Darwin wrote that the animals on oceanic islands would be well worth studying. The reasons for this intense interest stems from the fact that the life on many islands has an independent evolutionary history to that pursued by continental counterparts. Many oceanic islands are volcanic in origin, Inaccessible is no exception, and this means that all the original colonists must have immigrated from somewhere. The remoteness of Inaccessible has resulted in a marked faunal imbalance, many common groups of organism have simply never made a landing. Those that did found a virgin environment free from their usual predators and/or parasites and so selection pressures were much reduced. Many species could therefore expand their ecologica ranges and so occupy new vacant niches. On Inaccessible this occurs amongst several groups of organism. The isolation of these colonists from the parent population on continental mainlands meant that in time these populations diverged. The small size of island populations results in relatively rapid evolutionary rates and the build-up of a unique (endemic) fauna and flora. This is precisely the situation on Inaccessible Island.
Our job then was to make extensive collections of all groups of invertebrates from each major habitat. In certain cases this proved rather difficult since strong winds and very wet conditions rendered many of the standard techniques such as pitfall traps, quite ineffective. The damage to the wind generator during a particularly strong storm early on meant that the light trap, designed to attract Lepidoptera at night, could no longer be used. Sieving also proved difficult since much of the vegetation and soil remained permanently sodden. Beating however did prove successful as did the very laborious but extremely effective technique of searching by eye armed with a pooter. Many thousands of specimens were eventually collected. The enormous task now is to demonstrate those species which are known from other islands in the group, those that are known from elsewhere and those that are new to science. This will obviously take some years to complete but already it appears that some land snails are new. Before our visit only some 50 or so species of invertebrate had been recorded from Inaccessible, when the full results of our collections have been established the total is expected to be more than double this number.

In addition to simply cataloguing those species found on these islands today we would also like to know something about the history of life on each island. For most groups of organism we will never know anything about this aspect because there are no deposits likely to vield fossil remains. This is not so with certain plants or indeed certain small freshwater invertebrates. There were two small lake basins that were now nearly infilled, one on the plateau (Dick's Bog) and another at Blenden Hall (Skua Bog). Sediment samples (about $2 \mathrm{~m}$ long) were taken through both bogs with a Hiller corer. These cores contain abundant remains of fossil pollen, diatoms and ostracods (small crustaceans). Detailed analyses of the fossil content at regular intervals $(5 \mathrm{~cm})$ through these cores will enable us to reconstruct the environmental history of the island during the time these sediments accumulated. Radiocarbon dating will tell us exactly what this period was (likely to be about 10,000 years).

The fieldwork is now over and the detailed laboratory work has begun. We have already discovered pollen of two plant species in the cores that must have been derived from populations in South America (i.e. the pollen has been transported a distance of over $4,000 \mathrm{~km}$ !). It might be as well to record here our thanks to various specialists who are currently working on our Inaccessible material. These include Dr. K. D. Bennett (pollen), J. R. Carter (diatoms), Dr. G. Fryer (Cladocera), Dr. R. Gale (wood), Dr. M. W. Holdgate (invertebrates), Dr. V. R. Switsur (Radiocarbon dating). 


\section{ORNITHOLOGY}

Often supporting large numbers of nesting seabirds and sometimes with their own peculiar brand of land birds, islands have always held a fascination for the ornithologist. It would be hard to find an island more fascinating than Inaccessible. Not without some surprise I found myself heading out of Capetown with the expedition in early October. Having just completed a four month stint on a tiny Scottish island (population: five humans, circa 67,000 birds) I was relishing the prospect of getting to grips with some of the southern ocean birds to replace the northern Puffins, Shags and gulls which I had left behind.

The voyage in 'Agulhas' was a most important period of familiarisation and we were indeed fortunate to have four ornithologists from the Percy Fitzpatrick Institute of African Ornithology in Capetown on board who made the task of identifying the tricky species so much easier. Soon we were becoming almost blasé about species which, when seen in Britain cause major excitement-Little Shearwaters, Wilson's Storm-petrels and Black-browed Albatrosses. In addition, of course, there were also the many species which have never been recorded in British or even European waters, the majestic Shy Albatross, elegant Antarctic Terns and the diminutive Grey-backed Stormpetrels. Many of the smaller species came on board, attracted to the ship's lights on misty wet nights, giving the opportunity for detailed examination in the hand. And how many people can honestly say they've had a Broadbilled Prion land in their gin and tonic? A complete list of the birds seen on the outgoing voyage is given in the list at the end of this article along with a complete record of all those species seen on the whole expedition.

And so to Inaccessible. It is convenient at this point to divide the report into the categories into which our work fell.

\section{Seabirds}

Virtually the entire world population of Great Shearwaters breeds within the Tristan group and the islanders frequently commented on how much the species had increased over recent years. The numbers on Inaccessible were clearly enormous, but attempts to get some idea of the actual size of the population were hampered by the thick tussock and poor weather at the critical time. However, some counting of occupied burrows within measured quadrats was carried out giving at least an indication of the density of nests within different habitats. Much easier to survey were the Yellow-nosed Albatrosses, and most of the island was covered in the census of this species. Sooty Albatrosses, present in much smaller numbers were also counted. Four pairs of Wandering Albatrosses were found, the relic of what was at one time a much larger population. Now with legislative protection the main threat to the Gonies' survival, persecution by man, has been lifted and the birds will, it is hoped, build up once more, albeit very slowly. Other breeding species included Sub-antarctic Skuas were scattered thinly over the island, the only

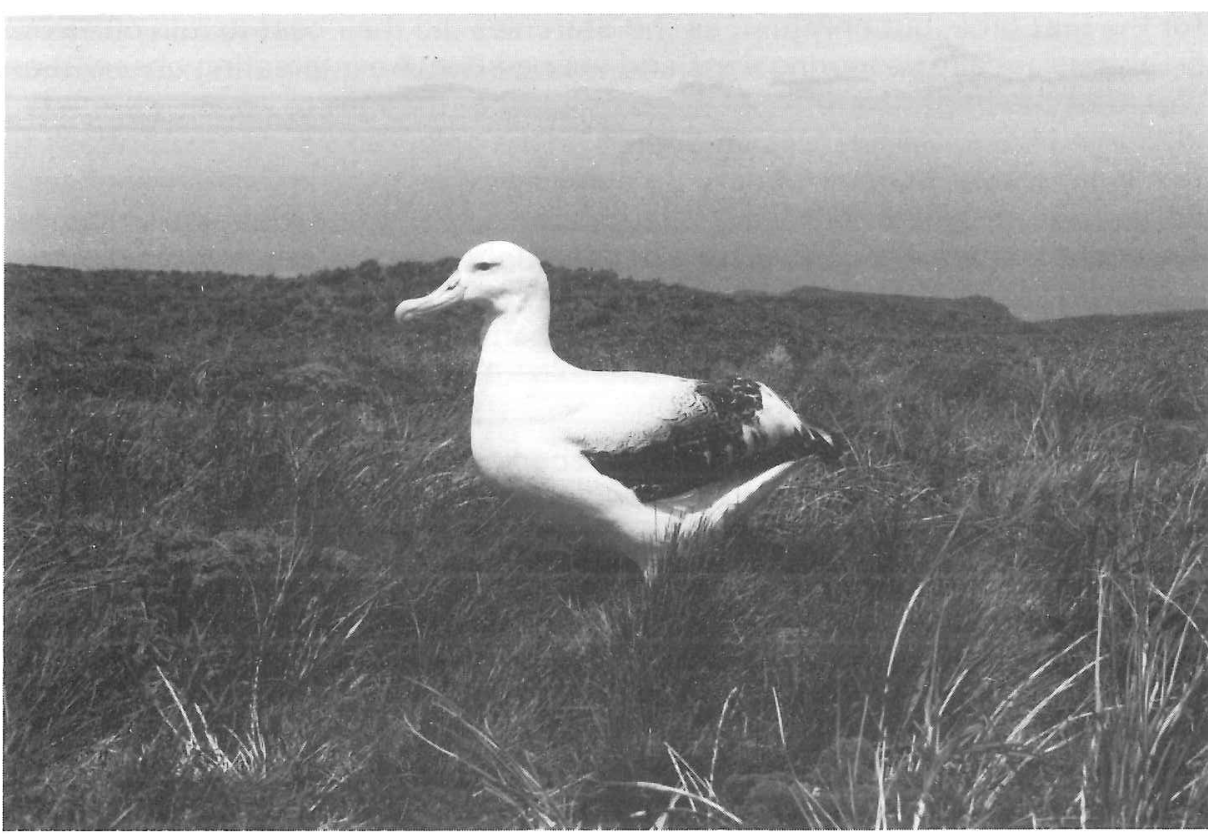

One of the few remaining majestic Wandering Albatrosses which nest on Inaccessible.

concentration being on the bog at Blenden Hall. Pellets collected at this site for dietary analysis show that Storm-petrels are the most important constituent.

Birds attracted to the hut's Tilley lamps on misty nights were the subject of a programme of biometrics to clarify the sub-specific status or otherwise of some species. Ectoparasites were also removed from these birds while they were in the hand.

Breeding condition was recorded to confirm the suspected nesting of some species, including the White-bellied Storm-petrel which for a long time tantalised us with its 'Piccolo in $\mathrm{F}^{\prime}$ whistle.

\section{Landbirds}

The island supports four species peculiar to the Tristan group-Tristan and Wilkins' Bunting, Tristan Thrush (Starchy) and a flightless rail, the latter restricted to Inaccessible itself. Little was known about these endemics, so virtually any information obtained would be breaking new ground. Work began with a detailed study of the Tristan Bunting, which was very common in the Blenden Hall tussock. Systematic watches were maintained to record every stage of the breeding cycle from courtship through nest building, incubation and rearing of the young. The incubation and fledging periods were ascertained 
for the first time, but only just, as the Starchies did their best to ruin our work by enthusistically devouring eggs and young alike. An interesting observation was that the bright 'variety' of Tristan Bunting, thought to be an age-related plumage phase, was in fact producing bright coloured young, in contrast to the dull chicks of the dull 'variety' (previously taken to be an immature phase). Separation of the two phases by distribution and ecotype was also evident the bright bunting living exclusively in the Blechnum and Phylica on the summit plateau and the dull ones being found only in the uniform Spartina tussock and scattered Phylica of the lower slopes, particularly on Blenden Hall. Further investigation will be required to determine the taxonomic status of these buntings on Inaccessible.

Wilkins' Bunting, the heavy-billed species, remained elusive during our stay, generally being found feeding quietly in the Phylica. Ten were colour marked at Wilkins' Copse on Blenden Hall, but only one was seen again indicating a mobile population even during the breeding season.

Far more conspicuous were the Starchies. Inquisitive birds, they soon learned to associate the hut with food and their tameness resulted in a number of colour-ringed birds being available for study. Although many obviously had nests (seen carrying building material or food) only one nest was in fact found, the dense tussock providing effective cover. This nest contained two newly hatched chicks which were measured regularly and their progress recorded until fledging. This was the first time that the young had been described. Attendance patterns of the adults were monitored in a series of nest watches, both parents being ringed.

Territoriality of the Inaccessible Flightless Rail was studied by plotting calling birds, and the discovery of two nests with eggs gave the unprecendented opportunity to examine incubation regimes and the posthatching behaviour of the chicks and their parents. Biometrics of individual young gave figures for growth rates and single birds and family parties were followed in the field to determine movements. Sadly, the Starchies again seriously affected this work by killing almost all our colour-ringed chicks (the loss of 'Blue-left' was hard to bear).

\section{Vagrants}

Two White-rumped Sandpipers (one adult and one first-winter) constituted a new record for the Tristan group. Up to four swallows, most likely also American in origin, were the only other vagrant recorded. We might perhaps have expected to see Cattle Egrets as these are reported almost annually from Tristan. An American Purple Gallinule was apparently heard on Tristan after Christmas and a mysterious "small, fast, bright blue bird" which frequented the flax for a while before our arrival on Tristan was not, unfortunately, seen by us.
Ringing

The use of uniquely numbered metal rings for marking birds is a widely used and valuable research tool, relying on the recapture or discovery of ringed birds to determine site fidelity, longevity and movement. Mist-and hand nets were used to catch the passerines and rail, and the seabirds were caught at the nest in the case of Mollies or extracted from their burrows in the case of Great Shearwaters. Birds coming to the lights at night were ringed in smal numbers and skuas were procured by a number of sometimes ingenious methods ranging from aerial nooses to simply walking up to the birds and grabbing them before they grab you (not a pleasant experience unless you particularly enjoy losing blood!)

The ringing of over 3,000 birds on Inaccessible (see table for details) almost doubled the number of birds that had ever been ringed in the Tristan group before and Wilkins' Bunting and the Inaccessible Flightless Rail were ringed for the first time. All these birds will hopefully result in the accumulation of data over the years either of birds found breeding back on Inaccessible or discovered in new nesting areas or when wintering away from the island the chances of a rail being found elsewhere are, at best, nil!). Ringing was done concurrently with censusing in the case of Great Shearwater and the Mollies. Not only does this mean that a marked population is established for future study but it safeguards against double counting. The young of these species were also ringed in some numbers so a nucleus of known age birds now exists.
Species

Yellow-nosed Albatross

Sooty Albatross

Soft-plumaged Petrel

Spectacled Shoemaker

Inaccessible Flightless Rai

White-rumped Sandpiper

Tristan Thrush

Tristan Bunting

Wilkins' Bunting

Sub-antarctic Skua

Great Shearwater

Antartic Tern

Common Noddy

Kerguelen Petrel

White-bellied Storm-petre

TOTALS
Broad-billed Prion

Pullus
573
18
-
-
-
-
1
1
-
19
109
2
1
-
-
-

724
Adult Total

$1,120 \quad 1,693$

$18 \quad 18$

$5 \quad 5$

$107-108$

44

$\begin{array}{ll}44 & 45 \\ 10 & 10\end{array}$

$17 \quad 36$

$980 \quad 1,089$

-

1

1

15

2,350
2
1

1

15

3,074
$16 \quad 34$

$15 \quad 15$

In addition, 51 Mollies, 2 Sooty Albatrosses and one Starchy were ringed on Tristan da Cunha and a single Leach's Storm-petrel was ringed at sea on the return journey. 
Species list in chronological order:

Capetown-Tristan da Cunha (06/10/82-14/10/82)

Hartlaub's Gull

Southern black-backed Gul

White-headed Petre

Black-bellied Storm-petre

Kerguelen Petre

Cape Gannet

Pintado Petrel

White-chinned Petrel

Shy Albatross

Soft-plumaged Petrel

Black-browed Albatross

Great Shearwater

(Giant Petrel sp.)

Great-winged Petrel

Long-tailed Skua

Wandering Albatross

Sub-antarctic Skua

(Storm-petrel sp.)

Sooty Shearwater

Grey Phalarope

Sooty Albatross

Yellow-nosed Albatross

Wilson's Storm-Petrel

Grey-headed Albatross

Northern Giant Petrel

Atlantic Petrel

Common Diving Petrel

Grey-backed Storm-Petrel

Antarctic Tern

Southern Giant Petrel

Rockhopper Penguin

Broad-billed Prion

Common Noddy

White-faced Storm-Petre

White-bellied Storm-Petre

Little Shearwater

Grey Petrel

(Prion sp.)

Additional species seen on return voyage: (18/02-23/02/83)

Leach's Storm-Petrel

Pomarine Skua

Cory's Shearwater

Jackass Penguin

Swift Tern

Arctic Skua

\section{Inaccessible:}

Rockhopper Penguin

Wandering Albatross

Black-browed Albatross

Yellow-nosed Albatross

Sooty Albatross

(Giant Petrel sp.)

Pintado Petrel

Broad-billed Prion

Kerguelen Petrel

Soft-plumaged Petrel

Spectacled Shoemaker

Grey Petrel

Great Shearwater
White-bellied Storm-Petrel White-faced Storm-Petrel Common Diving Petrel

Inaccessible Flightless Rail White-rumped Sandpiper Sub-antarctic Skua

Southern black-backed Gull Antarctic Tern

Arctic Tern

Common Noddy

Swallow

Tristan Thrush

Tristan Bunting
Little Shearwater

Wilson's Storm-Petrel

Wilkins' Bunting

Tristan da Cunha (22/12/82-22/01/83 and 10-18/02/83)

Rockhopper Penguin

Wandering Albatross

Black-browed Albatross

Yellow-nosed Albatross

Sooty Albatross

(Giant Petrel sp.)

Broad-billed Prion

Spectacled Shoemaker

Great Shearwater

The success of the ornithological work on the expedition was due very much to team-work, with everyone contributing in one way or another. Dave Gilfillan spent many hours bunting watching (not the most exciting of occupations, it has to be said!) and also helped with Molly ringing, as did lan Best. lan also did some pioneering work on the rails, positioning himself at one nest armed with notebook and camera and not appearing to move for days. Nelson and Andrew proved to be experts at "Petrel-grovelling" and were invaluable in that field. Nelson also impressed us all with the speed at which he could take off across the ferns in pursuit of Mollies and put us youngsters to shame (well, me, actually). But special credit must be given to Dave Briggs whose sheer hard work and enthusiasm, even when up to his waist in mud in the Skua bog, or having his hand lacerated by a belligerent Shearwater, or putting up with the moans of the ringer because we had only done 299 Mollies in a day, was the single most important factor in the achievements of the bird department. Thanks, Dave On another personal note I would like to thank sincerely Tim Beynon and Mike Swales of Denstone and Dr. Mike Harris of the Institute of Terrestrial Ecology for making it possible for me to go on the Expedition. 


\section{STILL PHOTOGRAPHY}

A complete pictorial record of the Expedition was obviously essential right from the start. There is, after all, no other way to show: Sponsors what you have done with their money or product, scientists what your are talking about, and friends or relatives where you have been for your holidays!

Early planning was based on an extremely optimistic estimate of how much money was going to be available for photography. We had also hoped for sponsorship from a major camera producer and approached the manufacturers accordingly. In the event, we were obviously considered not to be famous enough for financial support or gifts of cameras, but we received much useful advice; so, in the end, those of us who owned $35 \mathrm{~mm}$ cameras, took our own. This led to our taking a considerable assortment, much of it incompatible as far as lenses were concerned: 3 Canons, 4 Pentaxes, 2 Olympus and 2 compacts. All of these cameras performed well, but were found to be very sensitive to salt water-one siezed up completely within hours of a minor splashing after being apparently carefully dried.

We had considerable early discussions about which film to take. We decided that it should all be made by one manufacturer, so that we could more easily get fresh stock at the last moment. We received much help from Kodak and finally took 80 films of Kodachrome 64 for general photography and 20 of Ektachrome 400 for use in low light. This turned out to be particularly useful for photographing the flightless rails amongst the tussock grass. One hundred films was not enough and more were brought out in January, including Tri $X$ and Kodacolor for publishing purposes. Individual members brought film of their own and, in total, we used almost 200 films. The four types performed perfectly as expected, the Kodachrome in particular being excellent.

Following our return, the films were sent to various places for processing: Kodachrome to Kodak, Ektachrome to Colour Processing Labaratories and print film to the local photo shop. They were then returned to the photographer for numbering and listing - no problem if you have only a few but daunting if you have 30 films or more. The photographs and lists were then sent to John Woolley for cataloguing - a mammoth job completed in five months with help from other Expedition members. The collection will be stored at Denstone for the foreseeable future, where it is available for reference and for study purposes.

The chief co-ordinator of photography in the field was Nick Hall, himself a keen photographer who seldom goes anywhere without a camera. This was evidenced by the on-the-spot nature of many of the photos which, as a result, make a complete record of the Expedition and include candid, even entertaining, as well as documentary shots. One of the features which also comes across, in the slides especially, is the way in which the photographic skills of the rest of us developed during the Expedition. Although this doubtless happened in other spheres as well, it is only shown-up and recorded in the case of photography. The overall standard is thus quite high, an important aspect considering the rarity and scientific value of many of the photographs only a very few of which can be reproduced in this volume.

\section{CINÉ PHOTOGRAPHY}

It was surprising to discover, in the present day, that the B.B.C. still uses $16 \mathrm{~mm}$ ciné film in preference to video. We had originally planned to take video equipment with us on this Expedition, though conscious of its disadvantages, as it was cheaper to use. So, on making this discovery, we were faced with a considerable increase in cost, particularly for film. By good fortune, however, we also learnt that the B.B.C. was making a film about flightless birds of which one of the most unusual is only found on Inaccessible Island. I therefore offered my services as ciné photographer to the B.B.C. for filming the Flightless Rail and, after submitting an example of my film work, was accepted.

Thus began one of the (many) interesting aspects of the Expedition's preparation. The B.B.C. Natural History Unit in Bristol hired and made available to us all the necessary equipment: Bolex camera, lenses and an $8.5 \mathrm{~kg}$ tripod which we later named Bertha, as well as sound recording equipment. By the time we set off, we had enough film and tape to document the Expedition, as well as the wildlife on Inaccessible for which we were also given the necessary licence by the Tristan Administrator, Colin Redston.

After landing on the Island, the difficulties facing us became very apparent: The weather, the terrain and, not least, the time. But we soon discovered another: Co-operation of the wildlife, especially the Flightless Rail, our primary target which, we discovered lives almost underground and is extremely sensitive. We first had to find good possible places to film it. Two sites were recommended: One a semi-circular area at the top of the beach on a regular run used by at least one family of rails, the second an opening in dense tussock at the edge of a peat bog. After a little 'gardening' I settled down at the first on a comfortable seat of whale bones to observe and, hopefully, to film. I soon discovered that 'run' was the operative word: No sooner did the birds come into the opening that they darted across it. After a day or two, I hoped they would get used to the exposure and to me, and this they did only to take an instant dislike to the sound of the ciné camera and dive for cover. The process was not made any easier by the fact that the bird is only the size of a four-day old chick when full-grown, is black in colour and had to be filmed at (its) eye level. 
Following many hours of frustration at the first site, I decided to try my luck at the second. The only way to prepare this was to flatten part of the tussock to let more light in, sit on it and again wait for the birds to appear. Once more, each would dart for cover on seeing the "big eye with the whirring noise behind it;' but the cover had now been flattened, so it would take the only escape hole open to it - as often as not that at the bottom of my trouser leg! However, just occasionally, inquisitiveness got the better of it: It feeds on centipedes and insects for which it searches any small crevice in the tussock, the new 'corners' to explore were of course to be found up the camera tripod and even my legs! Filming such a bird with a camera which focuses only down to two metres does present difficulties under these circumstances.

Eventually, some sequences were obtained of this elusive little bird, and of various other bird species on the Island, some of them for the first time ever. The circumstances under which they were taken meant that they were not always up to standard but, together with shots of the Island and of the Expedition members going about their business, they have been documented. Recordings of a range of sounds and songs form the necessary background to a film of Inaccessible Island. For all of this we are grateful for the very considerable support and advice given by members of the B.B.C. Natural History Unit at Bristol, especially Producer Dilys Breese.

\section{COMMUNICATIONS}

Radio communication was a vital ingredient of the D.E.I. but one which caused a surprising number of headaches. Ideally, we planned to have powerful enough radio to keep us in daily contact with Tristan, and a trained operator as a member of the Expedition. In fact, we had neither! We had insufficient funds to afford the type of radio we envisaged and our plans to train someone for the job seemed to be thwarted. In addition, owing to the recession, the firm who had originally offered us the loan of a generator was unable to do so, while our attempts to enlist the Army's help failed due to the Falklands crisis.

We obtained expert advice at an early stage and it was established that we could use a low output battery-powered radio, provided we had line of sight with Tristan. At that stage, we were planning to establish our base at Waterfall Beach, so we went ahead and obtained 'walkie-talkie' sets with the generous help of South Midlands Communications. In the event, our base was at Blenden Hall from where we could not see Tristan, hence the need for the

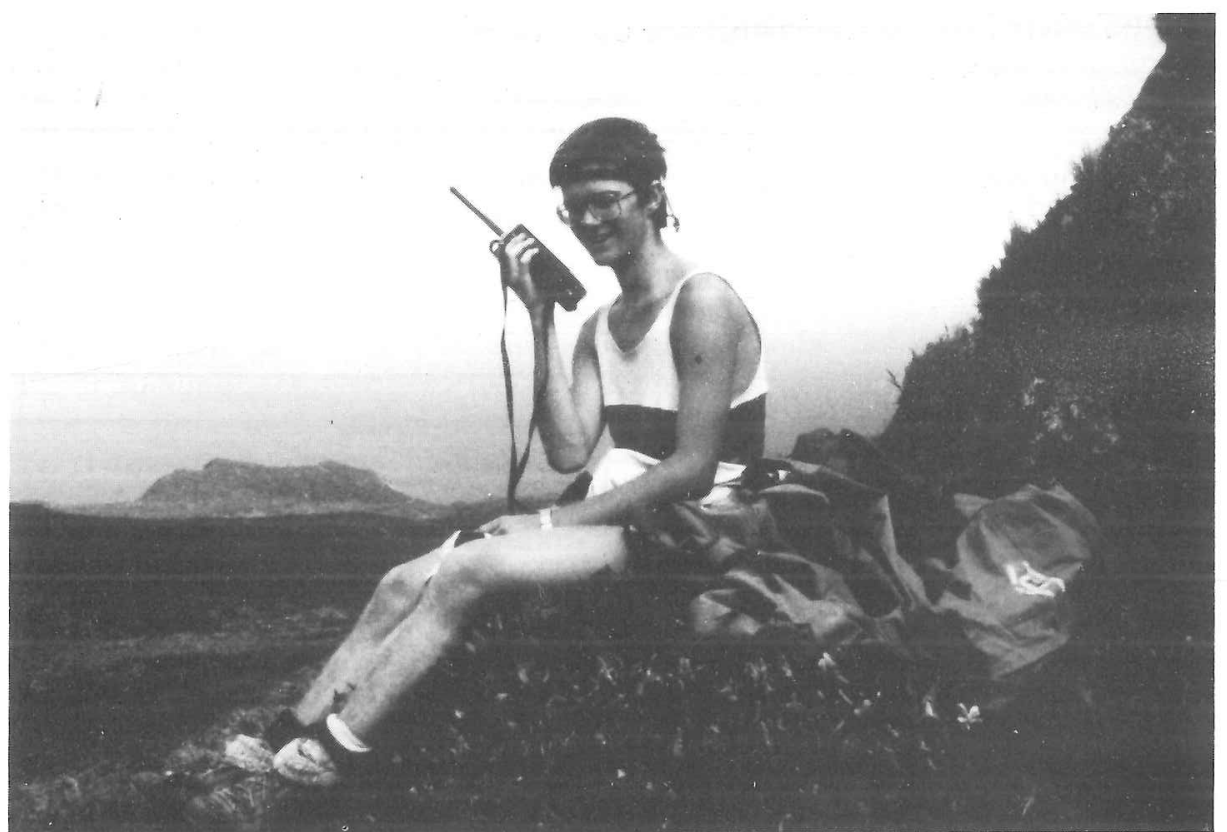

David talking over the radio to Tristan after having climbed the cliffs to do so.

trek up the mountain every time we wished to make a 'sched.' However, it was soon found that, although we could then see Tristan the radio station was not in sight! It was also necessary therefore for someone there to tramp nearly two miles every time we had arranged to come on the air. For doing this chore, we have especially Richard Grundy (Assistant Schoolmaster) to thank. He trudged out in all weathers, as did the Team members at our end. Hardly a satisfactory arrangement, but it worked and, from the safety viewpoint, this was vital.

Once our news reached Tristan, it was possible for radio amateurs there, especially Lorna (ZD9YL) and Andy (ZB9BV) to relay it to the outside world. Similarly, important messages could be sent by commercial channels and we became adept at interpreting cablese. For transmitting news, we were most fortunate to have a keenly interested 'ham' (Tony Smith, G4MDJ) living in Denstone at the time and another (Peter Walker, G4HHH) near John Woolley's school (Flying Hall) in North Yorkshire. So, if the radio waves were not getting through to one, they were nearly always received by the other. A regular network was thus set up and we are most grateful to all those concernedoften there were relays through ships, especially 'Tristania' and Peter Warren (ZD9BUMM), through America and St. Helena-for making it possible for all at Denstone and at home to be kept informed. 


\section{TRISTAN DA CUNHA}

Leaving the flat-topped cliffs of Inaccessible, the view in front of us that December day was a large volcanic cone which was the Island of Tristan da Cunha with, just below its peak, the typical band of cloud. As we drew nearer and rounded a point we had our first sight of Edinburgh Settlement, the only inhabited part of the Island, flanked by the lava flow from the more recent volcano of 1961 .

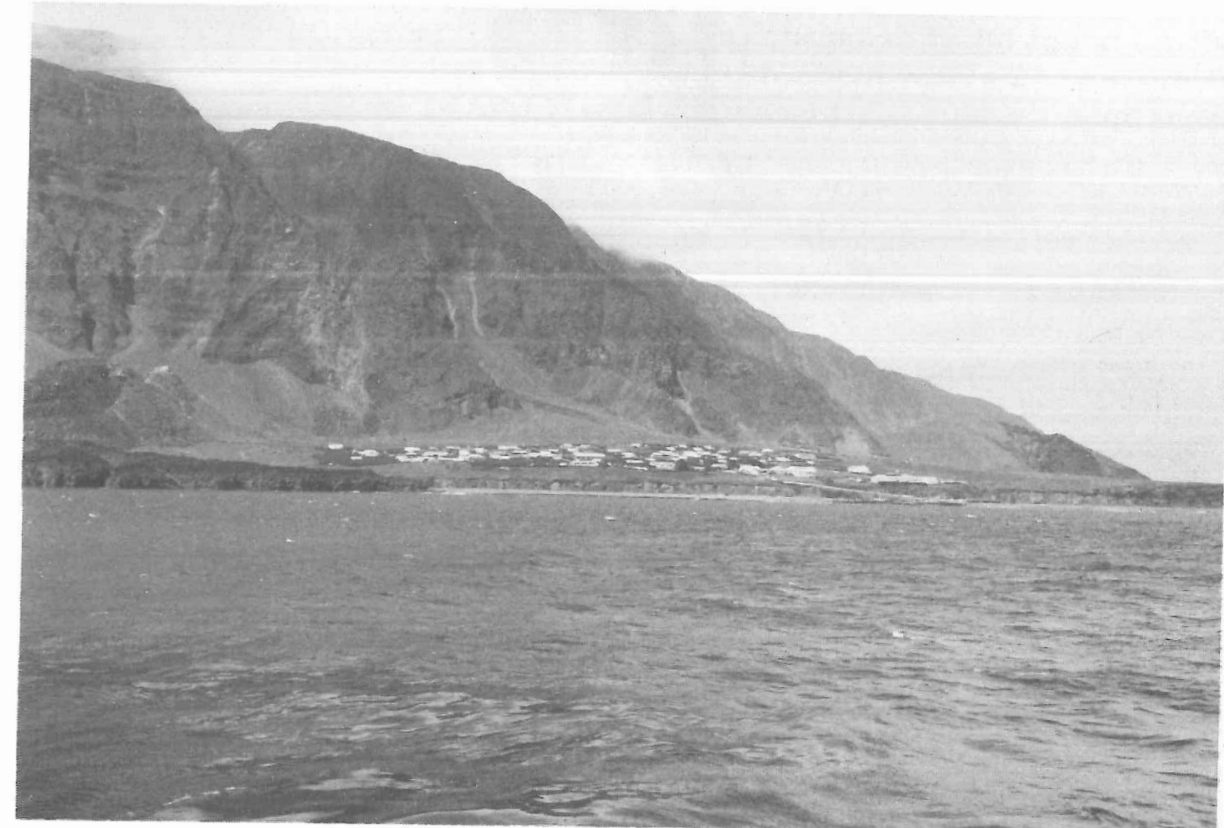

The settlement on Tristan dominated by the mountain behind and flanked by lava from the recently active volcano to the left.

As we entered the small harbour, which was protected by two man-made breakwaters, the road leading from it was full of Islanders who had come to welcome us to their Island and also to welcome home two of their fellows, Nelson Green and Andrew Glass who had been our guides on Inaccessible up to then. The welcome we received on Tristan was more than warm: The first night there we were all invited out to dinner.

The houses on Tristan are very like crofters' cottages in the North of Scotland or Ireland. Most of them have corrugated iron or asbestos roofs, although there are still a few examples of thatched cottages left. The houses are built of local stone - "tuff" - which can be cut with an axe. In the past, the wood used for furniture was driftwood, but now much is imported from. Cape Town. You enter a typical Tristan cottage through a low door into the kitchen where there is a fire used for cooking, as well as a modern gas stove.
All is kept spotlessly clean. You then go into the living room which has brightly painted wooden walls; adjacent is the bedroom or rooms depending on the number in the household. All the houses have brightly coloured interiors, small windows and are divided by wooden partitions. Each house has a small garden in which the flowers are beautifully kept, usually a small lawn on which a lamb is tethered and all surrounded by a low wall and tall flax to act as a windbreak.

Concrete roads run through the village, connecting the widely spaced houses. There are not only dwelling-houses in the Settlement, there are many other buildings. The local school is a modern, single-storey block holding five classes (infants to age 15) in separate classrooms, with two expatriate teachers, two island teachers and a trainee (Lorna, who, with her sister Valerie are the first Tristan Islanders to come to Coll). The school is well equipped, with a good library and an assembly hall with a stage. Scouts and Brownies are the most popular club activities outside school.

The Island is administered by a British Administrator whose home is the Residency for the time he is on Tristan. There is a local community building known as the Prince Philip Hall (to commemorate the Duke of Edinburgh's visit in 1957) where there is the Island's only pub and where a film is shown on a Monday night and a dance held on a Saturday night. There is St. Mary's Anglican Church which was built by the Islanders to hold about 120, with services taken by the expatriate Chaplain, and also a Catholic Chapel for the small Catholic community.

There are a few modern buildings on the Island, such as the Treasury (the only two-storey one) which includes the Post Office. This is as profitable, through philately, as the Island's main industry, crawfishing, for which there is a separate processing plant to prepare the fish for shipping to Cape Town. There is also a modern six-bed hospital with a resident expatriate doctor. All these buildings are white and clean-looking.

A typical day on Tristan would start at dawn with the sounding of the 'gong' which announces to the whole community that it is a fishing day. The men collect together their oilskins while their wives prepare their packed lunches: the men then make their way down to the harbour, load their 'pots' into a boat and wait to be hoisted into the water. They leave the harbour and can go wherever they like to fish. All they do is to drop the pots over-board and then fish for bait for their pots the next time they go fishing. In the late afternoon, they pull up their pots and head back to the harbour where their wives have a flask of tea waiting for them. Their catches are weighed and then taken up to the factory where the crawfish are processed late into the night by women.

There are many seasonal occasions in the Tristan calendar, some of which are agricultural, others more festive. The two agricultural occasions in which we took part were sheep-shearing and potato-harvesting. The sheep, which are owned by individuals, are brought into the pens where they are sheared 
by their owners. Carding and spinning of the wool is another communal activity, the wool then being used for making socks and jumpers. These make ideal presents, and we were fortunate recipients of many each, especially socks with their multi-coloured top bands denoting messages of affection! Late January is the harvesting time of the potato crop, which again is done by individual families. This occasion is one of the most important as the potato forms the Islanders' staple diet. Potatoes are grown in quite small 'patches' about two miles from the Settlement to where the crop is brought back using the traditional bullock cart as well as the modern tractor and trailer.

There are occasional trips: Up the mountain to collect sheep, which involves a 2,000 foot climb; to other parts of the Island such as Sandy Poin to collect apples, which takes forty minutes by boat. Visits to the other parts of the Island are always for a definite purpose; few Islanders have ever been to the summit.

Leisure activities include games, which most of the young people play such as: Football (which we also played and the Islanders won convincingly) cricket (which D.E.I. won) and hockey. Non-sporting activities include the film every Monday night, a video on Sunday night and dances. The community also has its one internal radio station, Radio Tristan, broadcasting mostly music. Dances are held to celebrate special occasions like weddings and twenty-first birthdays (Clive Siddall had his while we were there). There is a mixture of disco and their own traditional dances. One of these is the pillow dance which is started by a lady who places a pillow at the feet of and then kisses the man of her choice; he then picks up the pillow and proceeds to and kisses the lady of his choice; this eventually leads to a large conga. The music is provided by either a record player or the Islanders' own band.

The food on Tristan is excellent. The Islanders rely on only a few imported items such as flour-everyone bakes their own bread. They rely heavily on fish and potatoes and they have many ways of cooking and preparing these. For meat, they use lamb, beef and chicken. There is no milkman on Tristan: Milk comes fresh, straight from the cow. There is some home-made butter, but no cheese. A few vegetables are grown, such as carrots, onions, cabbages and pumpkins, all helped by the mild climate-it never freezes or snows at the Settlement.

To sum up Tristan in a phrase: It looks one of the most inhospitable places, but the people are the most hospitable in the world.
AFTERWARDS ...

Work connected with the Expedition did not end with our return to England on 28th February, 1983. In many ways, it was only just beginning: The media coverage of our return itself generated much activity.

Our scientific specimens had travelled with us to Cape Town where they were crated and trans-shipped to the 'S.A. Winterberg,' a large container vessel. She docked at Southampton and two of us went by pick-up truck to collect the two fair-sized crates weighing about half a ton, on 23rd March. Then followed the un-packing (more T.V. coverage) and the distribution of the various collections to specialists, mostly at the British Museum (Natural History) in London.

On 26th April, the equipment arrived back at Coll. It had been transferred from H.M.S. 'Endurance' in Port Stanley (Falkland Is.) to be re-packaged, brought home by air through Ascension Island to Brize Norton and thence to R.A.F. Stafford: Only four large crates - a very different consignment from the container-load that had left here eight months earlier. The various items were duly unpacked and dispersed-also a very different job from packingup last year.

Already awaiting our return was a large number of requests for our Inaccessible Island philatelic covers. This backlog had to be dealt with quickly and requests continued to come in for months afterwards. Also in the mail were requests of various kinds, mostly for information-all part of the followup. Photographic material had to be processed; slides labelled and catalogued, which alone took five months; those who had helped us were to be thanked; receptions were arranged; reports and scientific papers written-and all without undue interruption of otherwise busy lives.

All this has given us, and will doubtless continue to give us satisfaction; but perhaps none more so than anticipating the arrival at Coll. of the first pupils from Tristan, the Headmaster having awarded places to up to three at one time to continue their secondary education. It is thus hoped that we may to some extent repay the community on Tristan for their generosity and hospitality to us and, not least, for allowing us to map and explore their Inaccessible Island. 


\section{POSTCRIPT}

Many people have remarked that the Expedition was fortunate in 'the way things worked out.' This is not something about which one can be categorical: Good planning and organisation can account for much and are undoubtedly essential ingredients for the success of any expedition; but there were aspects of the D.E.I. which cannot be explained so easily. Such would include: Not a single injury sustained by any member in the most hazardous conditions, calm seas just at some of the most significant stages, favourable and timely shipping movements after what, for vears, seemed something unlikely to occur.

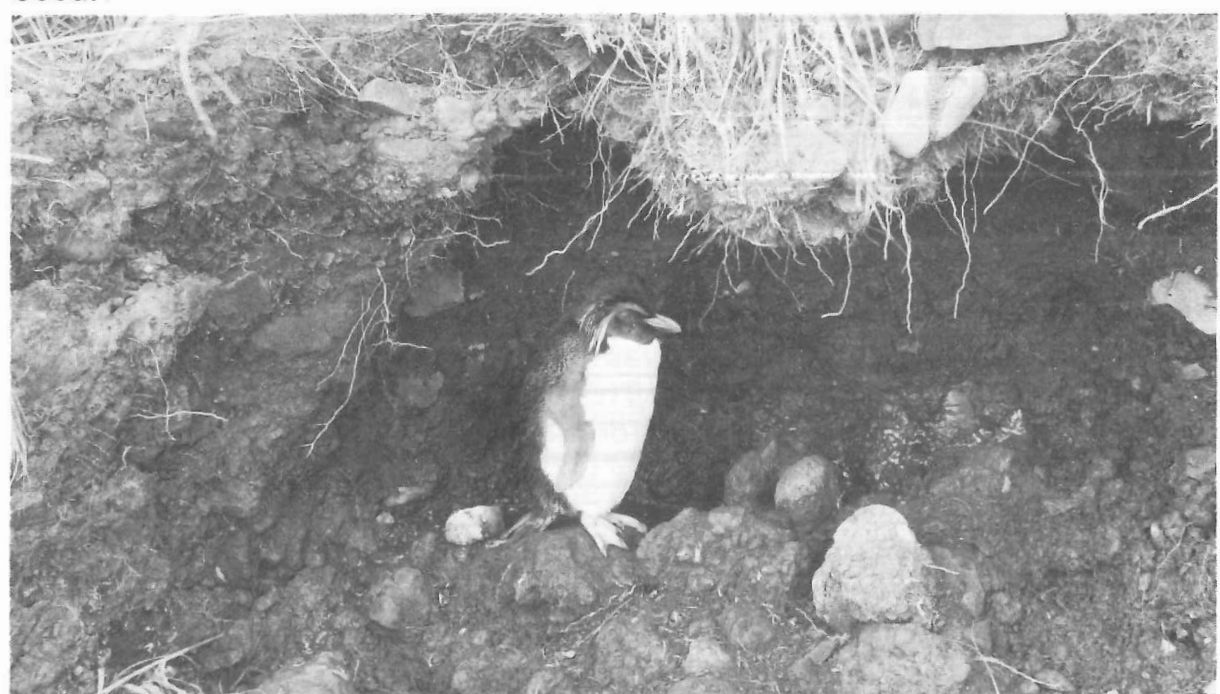

A sheltering Rockhopper Penguin shortly before moulting as we left Inaccessible.

Some people would give a deeper explanation. As a Church School of the Woodard Group, Denstone has a strong Christian tradition and, not surprisingly therefore, there are those among its members who believe in and practise prayer. Week by week after the Expedition set off, it was a special topic for prayer at the Sunday Chapel Service, two successive Chaplains agreed to be responsible for personal liaison among the Expedition members and their parents; but, in addition, there were many individuals of a much wider circle who requested information and specifically asked to be kept informed in order that they might pray for the Expedition and its members.

We are most grateful to them all who supported us in so many ways. That the Expedition was a success and that all went well is, we believe, attributable to more than just good will and good management. We, the members of this Expedition, have reason to be thankful to more than them alone. 


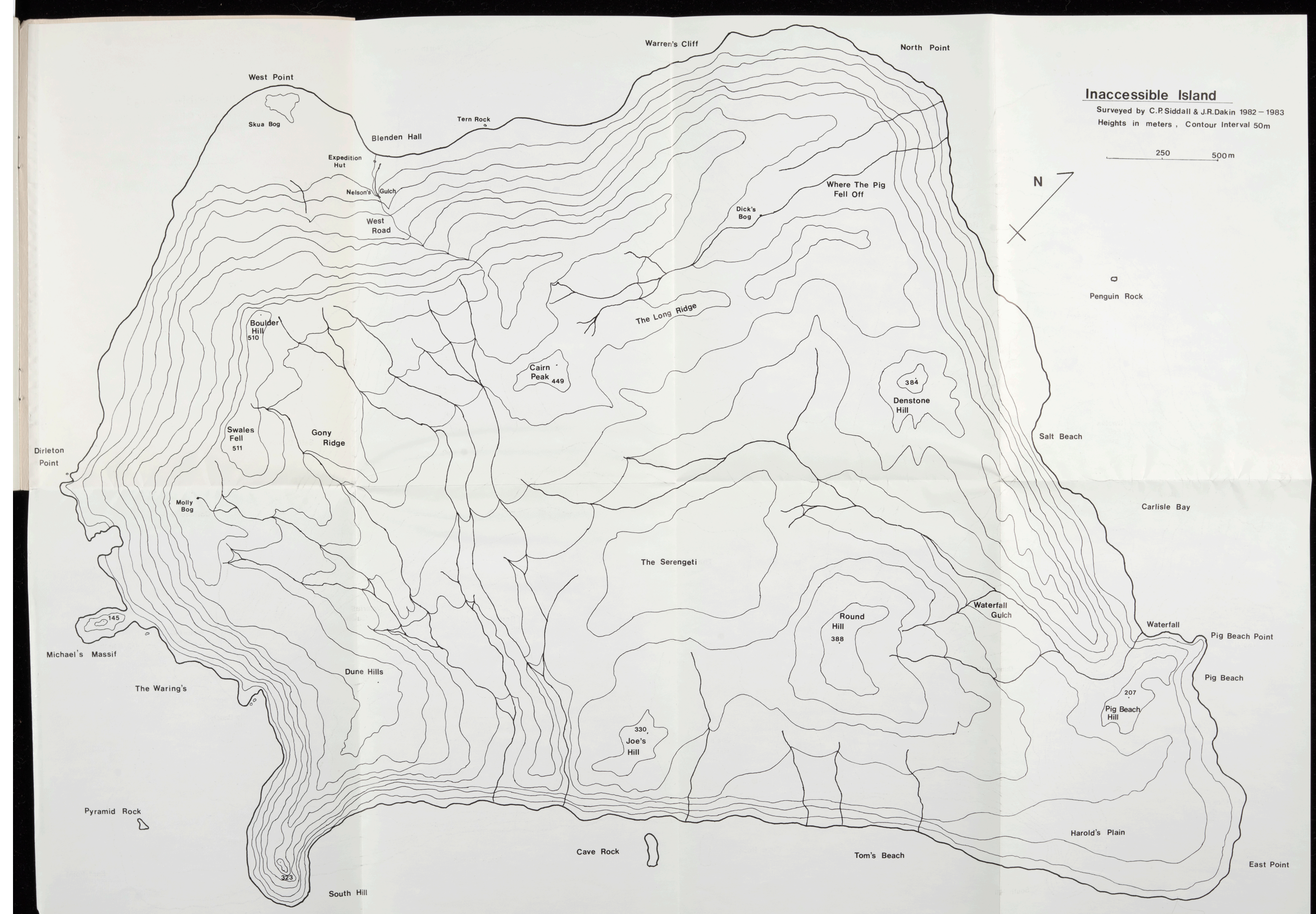

C.P. Siddall July 1983 